تأثير برنامج تعليمي باستخدام الوسائط المتعددة علي مستوي أداء مهارة التمرير من أعلي في الكرة الطائرة لتلميذات المرحلة الاعدادية

(اسراء منصور أحمد

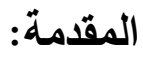

تثها الحياة المعاصرة تسارعا معرفيا يوما بعد يوم، وتزليدا واضحا في التطورات العلمية والتكنولوجية في كافة مجالات

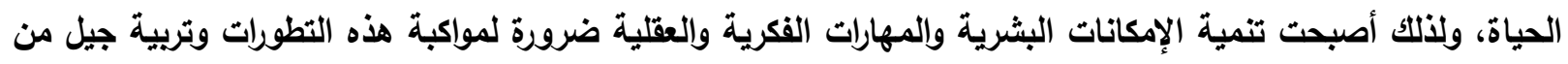

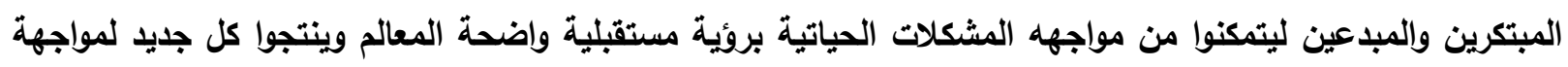
تحديات العصر الراهنة.

يشير كمال زيتون (\& . .rم) إلى ضرورة الاهتمام بتصميم البرامج التطليمية وتحميل المعلومات صوتا وصورة إذ يقوم

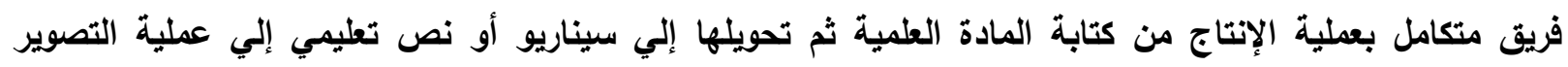

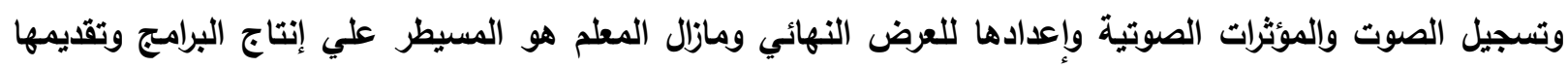
(lV: rr)

وتذكر إيناس حامد (ه . . بم) "أن التكنولوجية التعليمية تمثل منهجا في العمل وطريقة في التفكير وأسلويا في حل

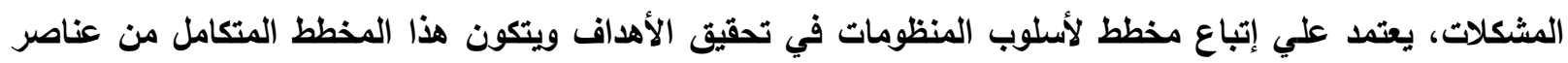

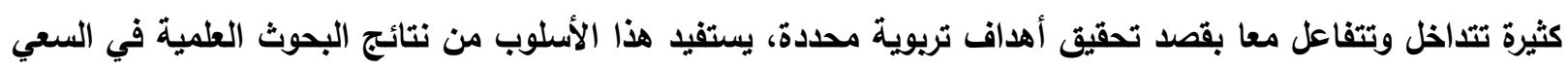

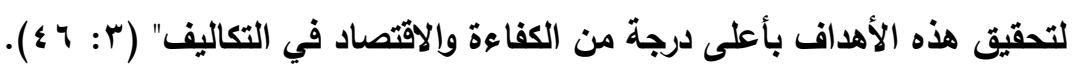

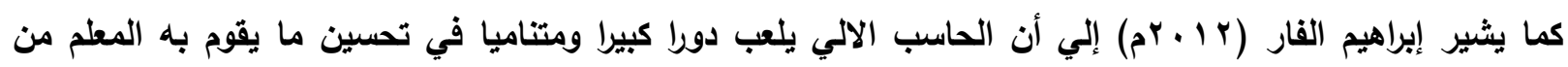

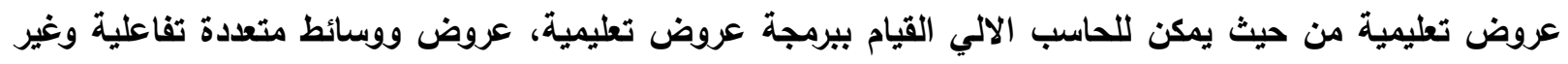

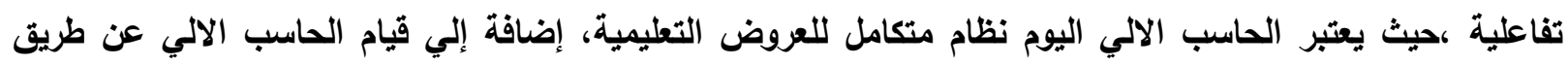

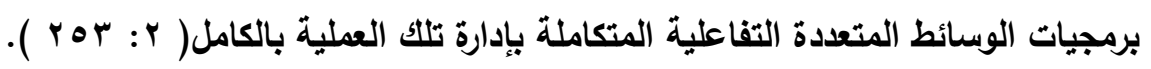

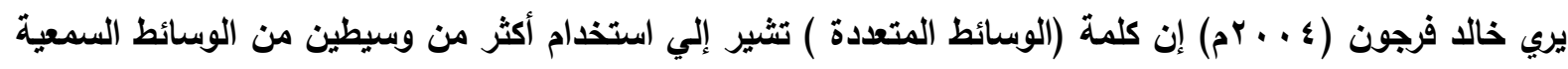

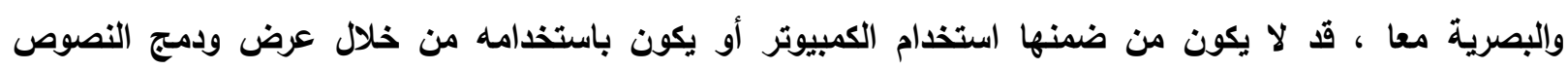

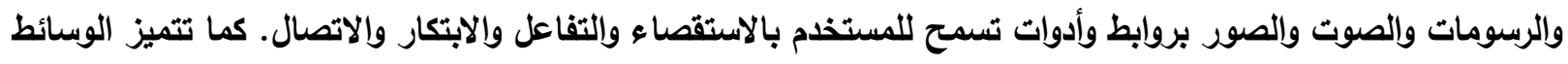

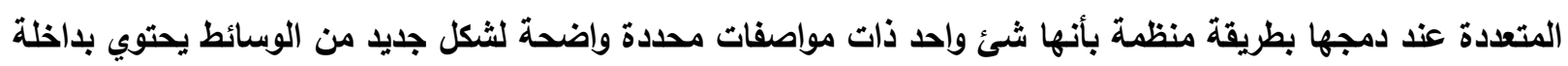

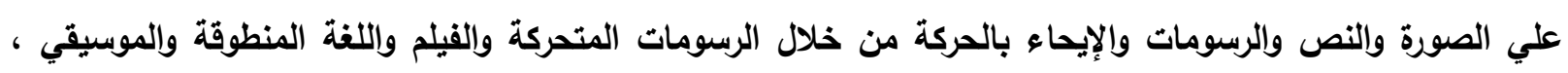

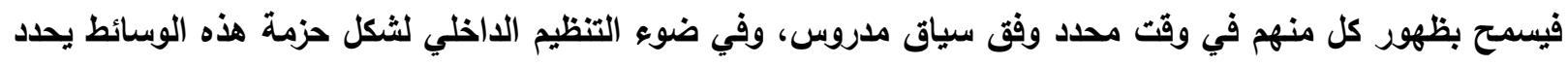

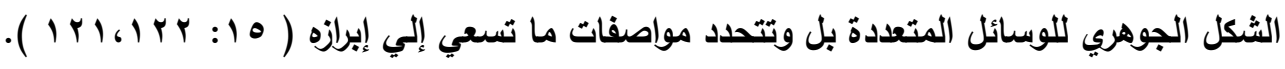


يعرفه حسن أبو عبده (11 • ب م) ان البرنامج التعليمي هو الذي يشترك فيه جميع التلاميذ، والغرض من هذا البرنامج

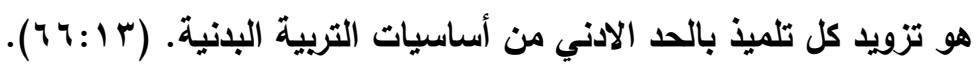

أهداف استخدام الوسائط المتعددة في مجال التعليم :

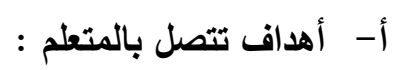

ا- تقليم البرامج التي تعرض الخبرات العلمية التي يصعب تقديمها في المدرسة نظرا لسرعة تطور نمو هذه

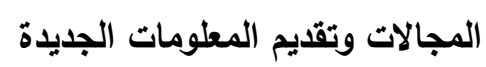

ץ- تنمية الاتجاهات والميول العلمية بين التلاميذ ، و الاهتمام بالتطور العلمي والتقتي ـ وأهمية ذلك لبناء

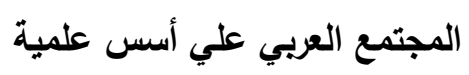

ب- التأكيد علي أهمية التفكير العلمي كأسلوب عصري في مواجهة المشكلات وجمع المعلومات ، وحرية التفكير

$$
\begin{aligned}
& \text { والبعد عن التعصب وتوخي الموضوعية وقبول الرأي الأخر } \\
& \text { ب- أهداف تتعلق بالمعلم : }
\end{aligned}
$$

1- تزويد المعلمين بالمعلومات التي تتصل بكل جديد في مجال تخصصهم ، حتى يواكب المعلم العربي عجلة

$$
\text { التطور في مجال العلم }
$$

ץ- تقديم المواد التعليمية التي لا تتوافر للمعلم في مدرسته ، مثل إجراء بعض التجارب المعملية التي تتوافر لها

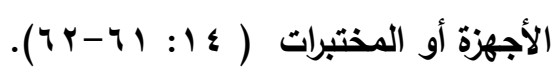

وتعد الكرة الطائرة من ضمن المقررات الدراسية في مناهج التربية الرياضية بالمدارس كما تقررها وزارة التربية والتعليم

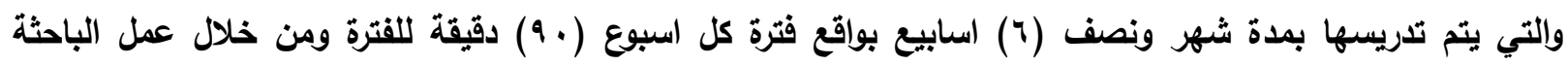
كمدرسة للتربية الرياضية لاحظت قصور في مستوي الاداء المهاري للكرة الطائرة كما لاحظت أن استخدام الأساليب

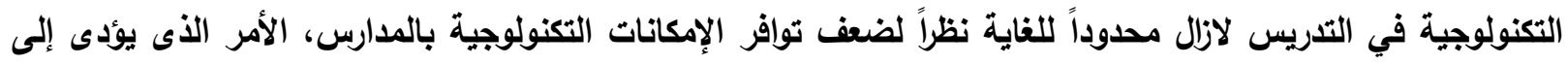

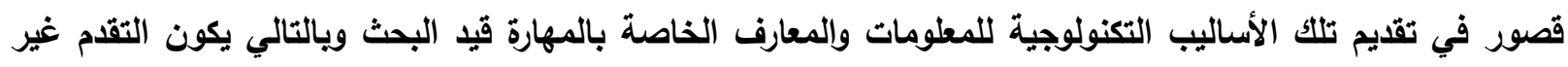
ملحوظ في النواحي المهارية.

- التمرير من أعلي للأمام باليدين فى الكرة الطائرة:

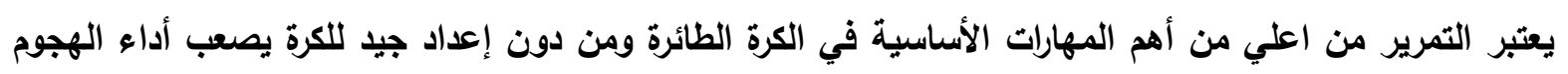

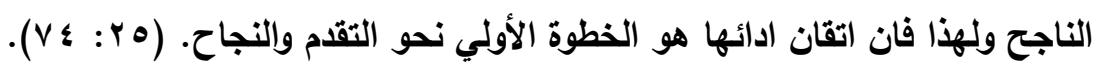
مشكلة البحث:

واستنادا على ما تقدم من مبررات تدعو للعمل على تطوير المقررات في مجال التربية الرياضية، والأخذ بالطرق الحديثة في التدريس، واستخدام الوسائل التكنولوجية في التعليم والتعلم، وسعيا من الباحثة في محاولة لملاحقة التطور

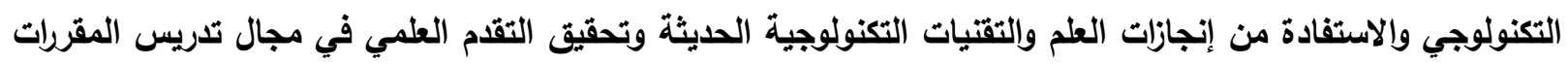
التريوية بوجه عام، وتدريس مقرر رياضة الكرة الطائرة بثكل خاص. 
مما سبق تتضح مشكلة البحث الحالي في أنه محاولة علمية جادة لمعرفة "تأثير برنامج تعليمي باستخدام الوسائط المتعددة علي مهارة التمرير من اعلي في الكرة الطائرة علي تلميذات المرحلة الاعدادية". أهداف البحث:

يهذف البحث الي التعرف على تأثير برنامج تعليمي باستخدام الوسائط المتعددة على مستوي اداء مهارة التمرير

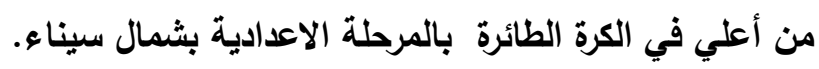

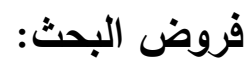

1 - توجد فروق داله إحصائية بين القياسين القبلي والبعدي للمجموعة الضابطة في مستوي أداء مهارة التمرير من

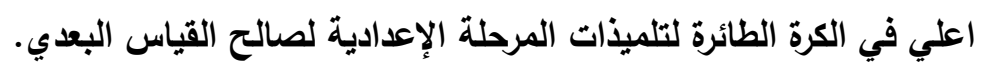

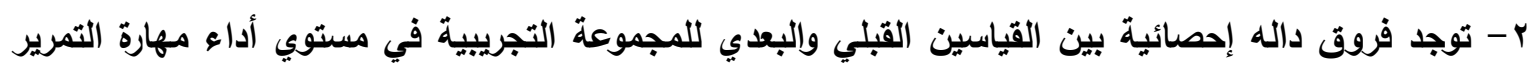

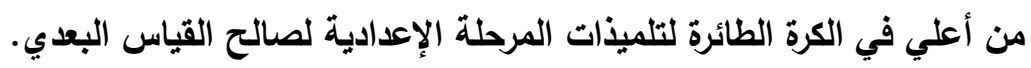

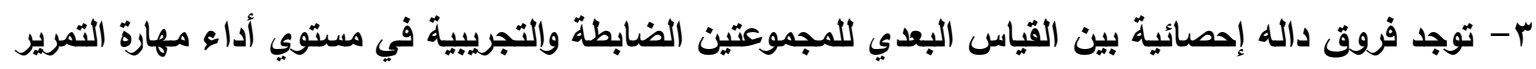

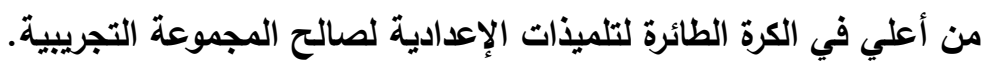
الارراسات السابقة: - شريف صلاح ( • ( • r م) بدراسة تستهدف تأثثر استخدام تكنولوجيا التعليم علي تعلم مهارات الكرة الطائرة ، علي عينة قوامها (· V V) طالب ، واستخلم الباحث المنهج التجريبي ، واهم النتائج التي توصل إليها الباحث بان ساهمت تقتية الوسائط الفائقة علي توفير الجها والوقت للباحث في شرح المهارات وإتاحة الفرصة لان بكان يكون

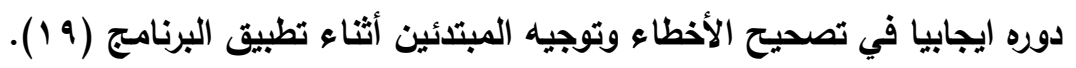

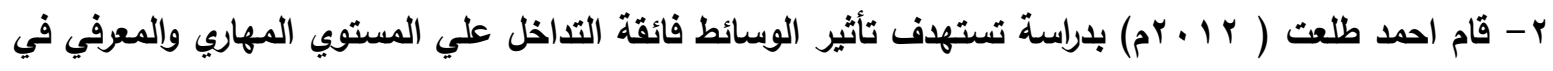
الكرة الطائرة لطلاب كلية التربية الرياضية، علي عينة قوامها لـ بـ طالب، واستخدم الباحث المنهج التجريبي، واهم النتائج التي توصل إليها الباحث أن المجموعة التجريبية التي تم التدريس لها بالبرنامج التعليمي باستخدام

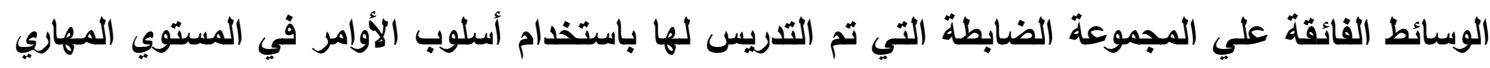

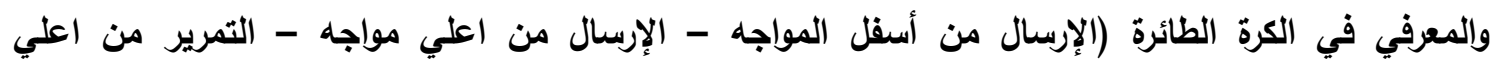

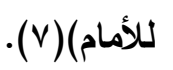

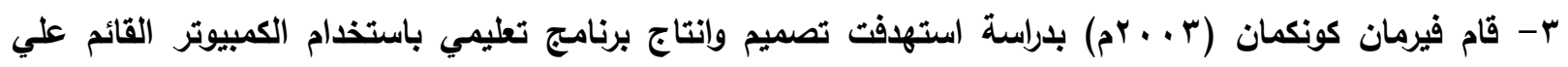

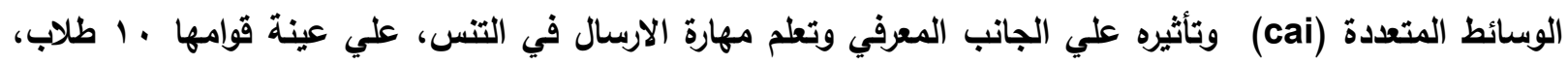
استخدم الباحث المنهج التجريبي، واهم النتائج التي توصل اليها الباحث هي أسلوب الوسائط المتعددة له تأثيرا ايجابيا في فئي

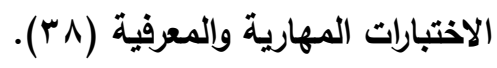

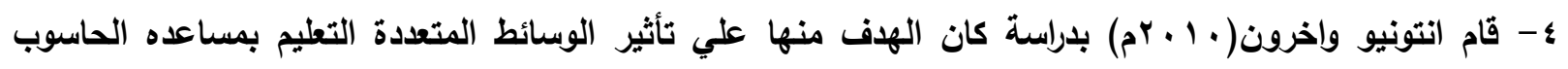

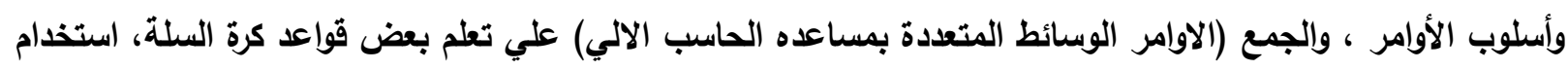

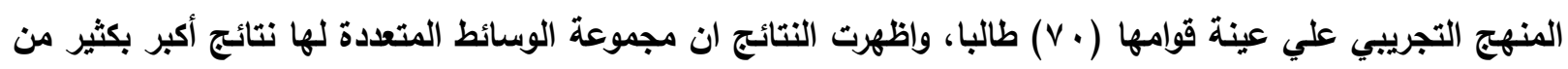
مجموعة اسلوب الأوامر في الاختبارات الأدائية وعلي العكس، فان اسلوب الألوان الأوامر يؤثثر علي الأداء في اختبار الفيديو 
وتحسين الطلاب، ويبدو أن طلاب التربية البدنية يمكن أن تتعلم قواعد كرة السلة من خلال الوسائط المتعددة من خلال

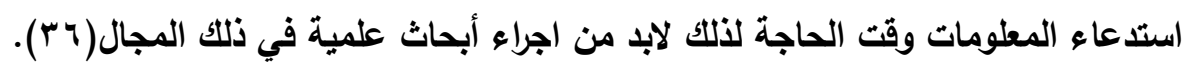
التعليق على الاراسات السابقة:

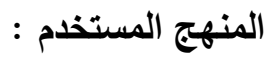

استخدمت جميع الاراسات المنهج التجريبي في إجراء الدراسات باعتباره انسب المناهج العلمية وملائمته لطبيعة وهدف ونوعية هذه الدراسات وتم إدخال المتغير التجريبي وهو تكنولوجيا الوسائط المتعددة والتعرف علي تأثير التكنولوجيا علي المتغيرات الأخرى ولكن اختلفت الدراسات في التصميم التجريبي فمنهم من استخدم تصميم باستخدام مجموعتين إحداهما تجريبية والأخرى ضابطة ومنهم من استخدم ثلاث مجموعات، وقد استفادت الباحثة منها في التوجيه بالنسبة للمنهج المستخدم أهداف الدراسات:

استهافت الدارسات السابقة العربية منها والاجنبية التعرف على تأثير بعض أساليب التريس وأسلوب استخدام الوسائط الالى ومقارنة بعضها ببعض والتعرف على تأثيرها على العديد من المتغيرات المعرفية كالتحصيل والمعلومات

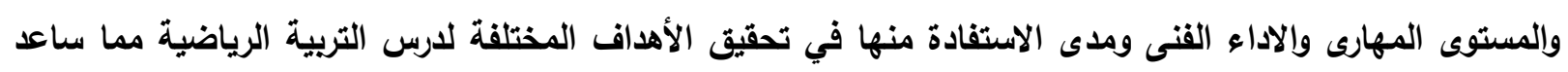

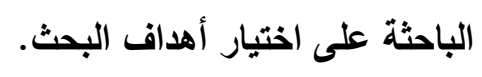

العينة :

اتفقت أغلب الاراسات في اختيارها لعينة البحث من حيث تراوحت العينة من ( • إلى • V V ) طالبا وطالبة والتي تم تقسيمهم علي المجموعات الضابطة والتجريبية داخل البحث حيث طبقت اغلب البحوث علي عينات من الطلبة والطالبات وكذلك غالبية المراحل التعليمية في المؤسسات التريوية.

النتائج :

اتضح للباحثة من خلال الدراسات السابقة أن معظم نتائج الدراسات السابقة أثبتت أن الأساليب الحديثة أفضل من طريقة التعلم المتبعة في تعلم المهارات الحركية في جميع الدراسات. إجراءات البحث:

\section{- منهج البحث: -}

استخدمت الباحثة المنهج التجريبي بتصميم المجموعتين إحداهما ضابطة والأخرى تجريبية للتعرف علي تأثير برنامج تعليمي باستخدام الوسائط المتعددة على مستوي أداء مهارة التمرير من اعلي في الكرة الطائرة بالمرحلة الإعدادية بشمال 


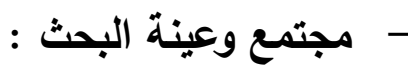

تم اختيار مجتمع البحث بالطريقة العمدية العشوائية من تلميذات الصف الثاني الاعدادي المقيدون بسجلات المدرسة

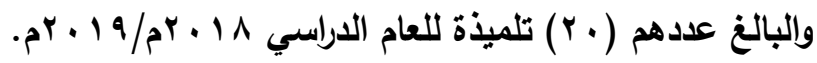

\section{- تجانس عينة البحث الأساسية :}

تم إجراء التجانس على عينة البحث الأساسية للمجموعة الضابطة و التجريبية والبالغ عددها (•r) تلميذات الصف الصف الثاني الاعدادي.

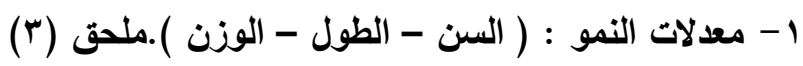

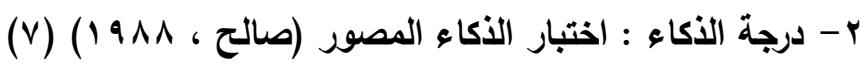
r- الاختبارات البدنية : استخذمت الباحثة الاختبارات البدنية لقياس الصفات البدانية لتلميذات قيدار البحث ؟ - تجانس عينة البحث في معدلات النمو ودرجة الأكاء .

جدول (1)

معامل الالتواء للمجموعتين الضابطة والتجريبية في السن والطول والوزن والأكاء ن ا=ن ب= =ـ

\begin{tabular}{|c|c|c|c|c|c|c|c|c|c|c|}
\hline \multicolumn{4}{|c|}{ المجموعة التجريبية } & \multicolumn{4}{|c|}{ المجموعة الضابطة } & \multirow{2}{*}{ وحدة القياس } & \multirow{2}{*}{ /المتغيرات / /الإحصا / / / / } & \multirow[b]{2}{*}{ r } \\
\hline معامل & الوسيط & $\varepsilon \pm$ & س - & الالتواء & الوسيط & $\varepsilon \pm$ & س- & & & \\
\hline$\cdots \wedge-$ & $1 \% .10$ & $\ldots r$ & 17.17 &.$\vee \vee q$ & 14.10 & $\cdot \ldots$ & 14.10 & سنة | & السن & 1 \\
\hline$. r \leq-$ & $108 \ldots$ & 1.80 & 107.1. & וM & 107.0. & r.r & 107.9. & سم & الطول & $r$ \\
\hline$. V Y-$ & $00 \ldots$ & Y.9V & $\bullet \varepsilon . Y$. & $. .0 \mathrm{~V}-$ & $00 \ldots$ & r.o\& & $0 \leq .1$. & كجم & الوزن & $r$ \\
\hline .7 & r... & r. & . ع. اس &..$\varepsilon r$ & r.o. & r.Mr & r.o. & درجة & الأكاء & $\varepsilon$ \\
\hline
\end{tabular}

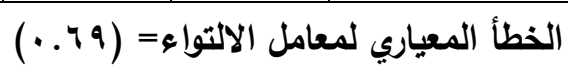

يتضح من الجدول (1) أن معامل الالتواء فى السن والطول والوزن والذكاء قد بلغ للمجموعة الضابطة على التوالي

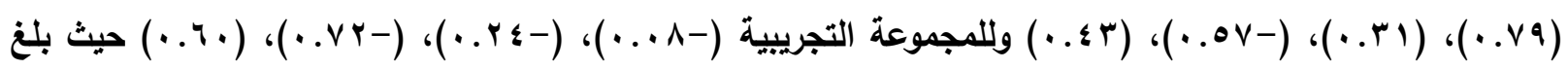

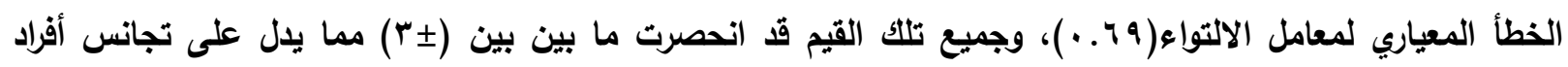
المجموعتين الضابطة والتجريبية في تلك المتغيرات.

- تجانس عينة البحث في الاختبار المهاري : 


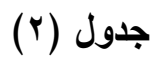

\begin{tabular}{|c|c|c|c|c|c|c|c|c|c|c|}
\hline \multicolumn{4}{|c|}{ ن } & \multicolumn{7}{|c|}{ معامل الالتواء للمجموعتين الضابطة والتجريبية في الاختبار المهاري قيد البحث } \\
\hline \multicolumn{4}{|c|}{ المجموعة التجريبية } & \multicolumn{4}{|c|}{ المجموعة الضابطة } & \multirow{2}{*}{ القياس } & \multirow[b]{2}{*}{ الاختبار } & \multirow[b]{2}{*}{ P } \\
\hline الالتواء & الوسيط & $\varepsilon \pm$ & 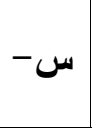 & الالتواء & الوسيط & $\varepsilon \pm$ & 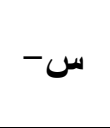 & & & \\
\hline$\ldots$ & $10 .$. & $\begin{array}{c}0 . \varepsilon \\
1\end{array}$ & $\begin{array}{l}10 . \\
\ldots\end{array}$ & or. & 18.0. & V.1. & 17.1 & درجة & التمرير على الحائط خلال التمرير من أعلى & 1 \\
\hline
\end{tabular}

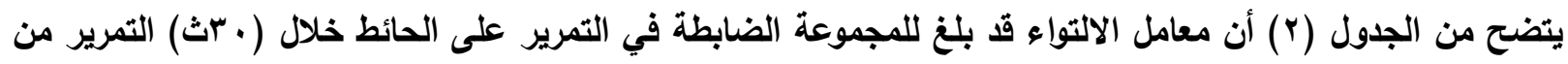
أعلى(هr. +). وللمجموعة التجريبية ( (...).

$$
\text { 1 - تكافؤ أفراد عينة البحث في الاختبارات المهارية : }
$$

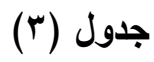

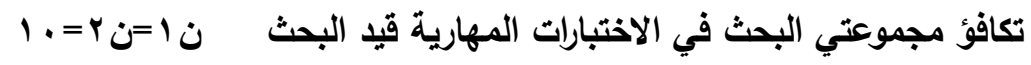

\begin{tabular}{|c|c|c|c|c|c|c|c|c|c|}
\hline \multirow{2}{*}{ |الإحصائية } & \multirow{2}{*}{ (U) } & \multicolumn{2}{|c|}{ مجموع الفروق } & \multicolumn{2}{|c|}{ متوسط الرتب } & \multicolumn{2}{|c|}{ المجموعات } & \multirow[t]{2}{*}{ الإحصاء } & \\
\hline & & ت & ت & ت & 10 & ت & ت & & \\
\hline. .09 & $\varepsilon r . .$. & $9 \wedge . .$. & $11 \% \ldots$ & ৭.^. & $11 . r$. & 1. & 1. & التمرير على الحائط خلال التمرير من أعلى & 1 \\
\hline
\end{tabular}

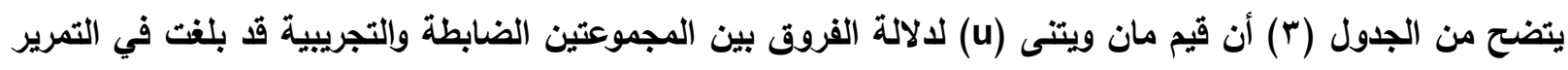

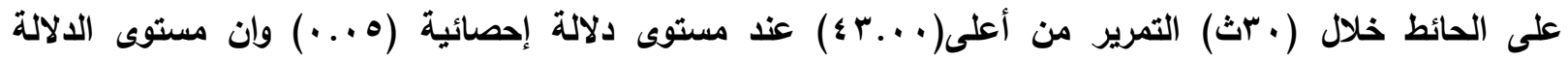

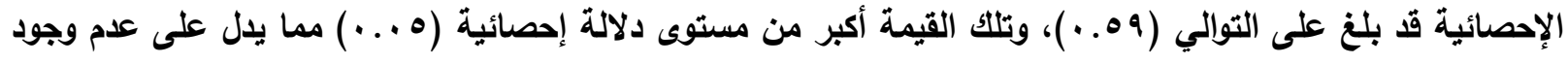
فروق ذات دلالة إحصائية بين المجموعتين في تلك الاختبار. وسائل وادوات جمع البيانات المستخدمة فى البحث :

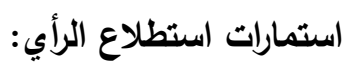

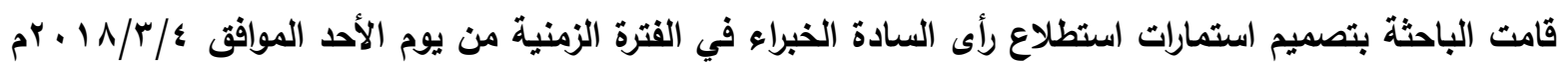

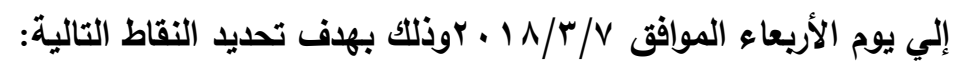

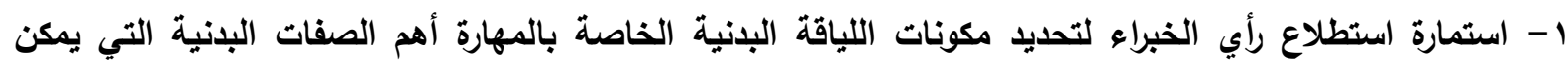

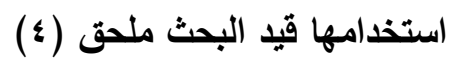

r- استمارة استطلاع رأي الخبراء حول عدد المدة الزمنية للبرنامج التعليمي و تحديد زمن الدرس التعليمي وتحديد عدد

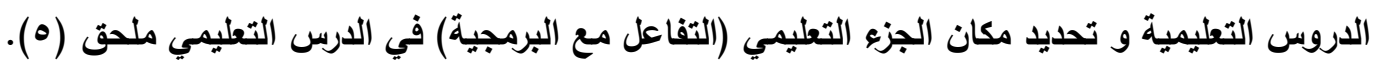
ץ- استمارة استطلاع رأي الخبراء حول التوزيع الزمني اللجزء التعليمي والتطبيقي للمهارة الثانية ملحق (†). 
وقد قامت الباحثة بعد تصميم هذه الاستمارات بعرضها على مجموعة من أساتذة كلية التربية الرياضية للتأكد من صلاحيتها العلمية وإمكانية اعتمادها عليها في جمع بيانات البحث. لماهد

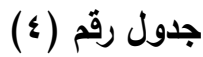

النسب المئوية لآراء السادة الخبراء حول ترتيب الصفات البدنية الخاصة بالمهارات قيد البحث حسب أهميتها

\begin{tabular}{|c|c|c|}
\hline الترتيب & النسب المئوية & الصفات البلنية \\
\hline 1 & $\% 1 \ldots$ & سرعة رد الفعل \\
\hline$r$ & $\% q$. & السرعة الانتقالية \\
\hline$r$ & $\% \wedge \diamond$ & المـرونــــة \\
\hline 0 & $\% \vee 0$ & القوة المميزة بالسرعة \\
\hline$\Lambda$ & $\%$ \%० & التـــــــــ \\
\hline
\end{tabular}

يتضح من جدول (ء) الصفات البذنية التي تم تحديدها بناء على رأى السادة الخبراء، وقد تم اختيار الصفات البدنية التي حصلت على نسبة (0 \% \%) فأكثر من رأى السادة الخبراء، حيث أصبحت الصفات البدنية التي تم ترشيحها من قبل سيادتهم كالآتي: الرشاقة، السرعة الانتقالية، المرونة، سرعة رد الفعل، التوافق. جدول (0) النسب المئوية لآراء السادة الخبراء حول تحديد أهم الاختبارات المستخدمة فى البحث

\begin{tabular}{|c|c|c|c|c|}
\hline النسبة المئوية & الموافقين & الاختبارات البدنية & الصفات البدنية & م \\
\hline$\% 1 \ldots$ & 1. & نلسون للاستجابة الحركية الانتقالية & \multirow{3}{*}{ سرعة رد الفعل } & \multirow{3}{*}{1} \\
\hline$\%$ & $\bullet$ & المسطرة لقياس زمن الرجع للأراع & & \\
\hline$\%$ & 7 & المسطرة للسرعة الحركية للذراعين & & \\
\hline$\% \vee$. & $\vee$ & العدو ^ا م من البدء العالي & \multirow{4}{*}{ السرعة الانتقالية } & \multirow{4}{*}{ r } \\
\hline$\% \varepsilon$. & $\varepsilon$ & العدو • م من البدء العالي & & \\
\hline$\% 1 \ldots$ & $1 \cdot$ & العدو · r م من البدء المتحرك & & \\
\hline$\%$ \%. & 7 & العدو لمدة • ب ث ث & & \\
\hline$\% q$. & 9 & ثني الجذع أماما من الوقوف & \multirow{3}{*}{ المرونة } & \multirow{3}{*}{$r$} \\
\hline$\% r$ & r & ثني الجذع خلفا من الانبطاح & & \\
\hline$\%$ & $\bullet$ & رفع الكتفين من الانبطاح & & \\
\hline$\% \vee$ & $\vee$ & الوثب ثلاث وثبات متتالية & \multirow{5}{*}{ القوة المميزة بالسرعة } & \multirow{5}{*}{$\varepsilon$} \\
\hline$\% 9$ & 9 & الوثب العريض من الثبات & & \\
\hline$\% \varepsilon$. & $\varepsilon$ & الوثب من الجري للهجوم & & \\
\hline$\%$ & • & الوثب العمودي & & \\
\hline$\% 9$. & 9 & رمي كرة السلة & & \\
\hline$\%$ & 7 & تمرير كرة السلة علي الحائط لمدة . ب ث & \multirow{4}{*}{ 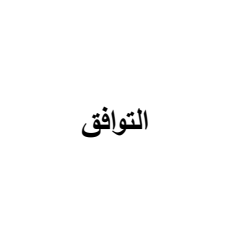 } & \multirow{4}{*}{ ๑ } \\
\hline$\% 1 \ldots$ & 1. & تمرير كرة الطائرة علي الحائط لمدة ه ب ث & & \\
\hline$\% q$ & 9 & تمرير كرة السلة علي الأرض لمدة . ب ث & & \\
\hline$\% \wedge$ & $\wedge$ & رمي واستقبال الكرات علي الحائط & & \\
\hline
\end{tabular}


يتضح من جدول (ه) موافقة معظم الخبراء على جميع الاختبارات المحدة للاراسة، حيث كانت النسبة المئوية

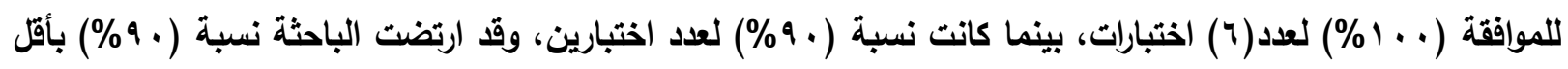
نسب يقبل بها الاختبارات في هذه الدراسة.

ع - أدوات قياس الصفات البدنية الخاصة بالكرة الطائرة: بناء علي أي السادة الخبراء قامت الباحثة بتطبيق الاختبارات التي تقيس الصفات الصنات البذنية المتعلقة بالبحث وهي: 1- 1 - نلسون للاستجابة الحركية والانتقالية.

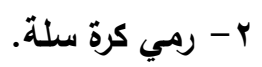

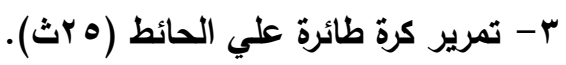

$$
\text { ع - العدو (·rم) من البداء المتحرك. }
$$

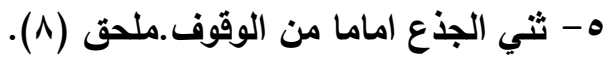

$$
\begin{aligned}
& \text { الأدوات والأجهزة المستخدمة فى البحث: } \\
& \text { 1- حاسب الالي ( كمبيوتز ) } \\
& \text { r - ساعة ايقاف } \\
& \text { r- شريط قياس } \\
& \text { ـ - ميزان طبي }
\end{aligned}
$$

ه- - السجلات والقوائم الرسمية الموجودة بالمدرسة

\section{1 - صدق وثبات الاختبارات البدنية :}

قامت الباحثة بالاطلاع علي الابحاث السابقة التي تناولت الاختبارات البذنية قيد البحث مثل كل من محمد جزر

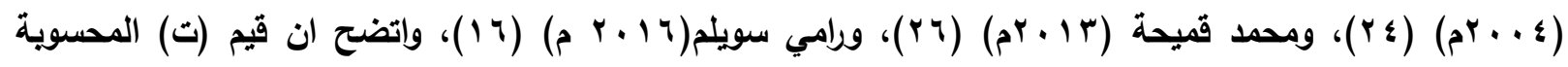
والدالة علي صدق تلك الاختبارات ذات دلالة احصائية عند مستوي (ه . . )، وقد استدلت الباحثة بتلك القيم لايجاد قيمة

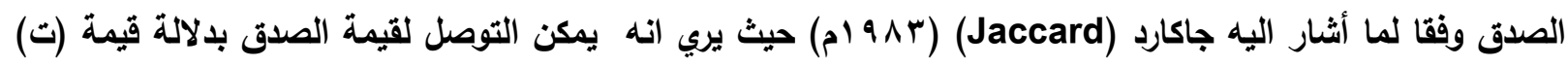
المحسوية عن طريق إيجاد الجذر التربيعي لايتا `

$$
E T A^{2}=\frac{T}{\sqrt{T^{2}+(N 1+N 2-2)}}
$$


جدول (†)

قيم معاملي الصدق والثبات للاختبارات البانية قيد البحث

\begin{tabular}{|c|c|c|c|c|c|}
\hline \multicolumn{2}{|c|}{ معامل الثبات } & \multicolumn{2}{|c|}{ معامل الصدق } & \multirow{2}{*}{ الاختبارات الإحصاء } & \multirow{2}{*}{ r } \\
\hline 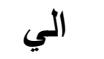 & من & 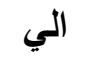 & من & & \\
\hline .990 &.$V r$ & .91 & $\because V Y$ & نلسون للاستجابة الحركية والانتقالية & 1 \\
\hline. .99 & $.9 \mathrm{~V}$ & $.9 V$ & $.7 \mathrm{~V}$ & ثي الجذع اماما من الوقوف & r \\
\hline. .99 &.$\wedge 1$ & $\cdot .9 V$ & $.7 \mathrm{~V}$ & رمي كرة سلة & $r$ \\
\hline. .99 & 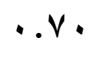 & $.9 \leq$ & $\because V Y$ & تمرير كرة طائرة علي الحائط (ه rث) & $\varepsilon$ \\
\hline. .91 &..$\wedge \wedge$ & . A V & 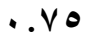 & العدو (· • م) من البدء المتحرك & $\bullet$ \\
\hline
\end{tabular}

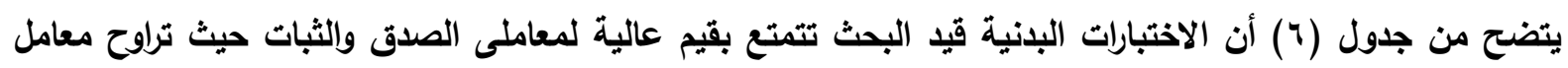

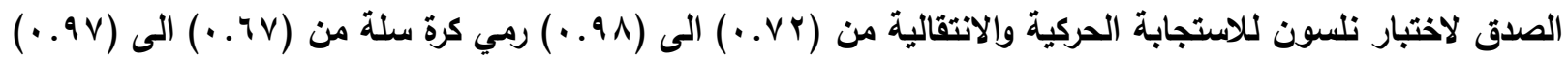

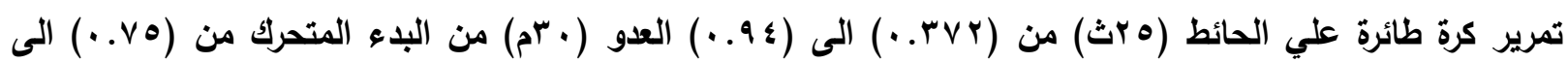

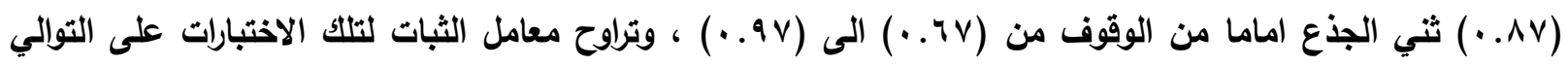

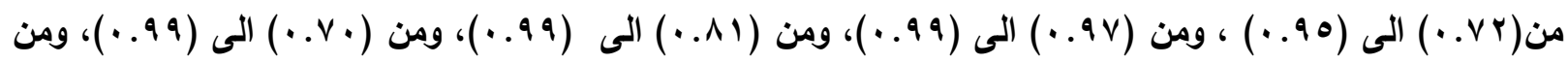
( ) (..^^)

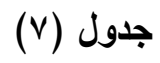

صدق وثبات الاختبار المهاري

\begin{tabular}{|c|c|c|c|c|c|}
\hline \multicolumn{2}{|c|}{ معامل الثبات } & \multicolumn{2}{|c|}{ معامل الصدق } & \multirow[t]{2}{*}{ الإحصاء } & \\
\hline الي & من & الي & من & & \\
\hline .90 &. .74 &. $.9 \mathrm{~V}$ &. .10 & التمرير من اعلي لمدة . ب ث & 1 \\
\hline
\end{tabular}

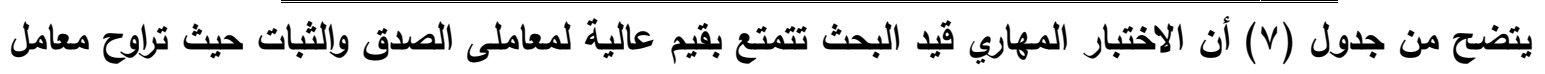

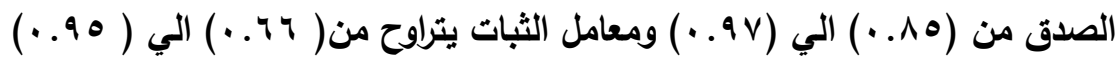

الدراسة الاستطلاعية:

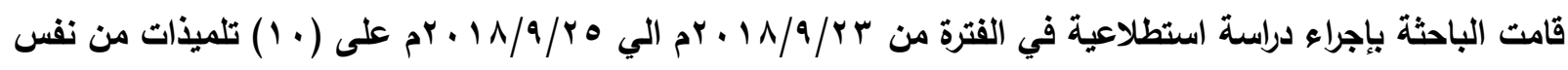

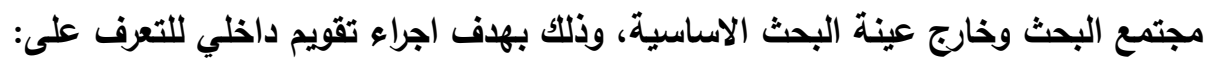

1- ا - مدى وضوح البرمجية التعليمية.

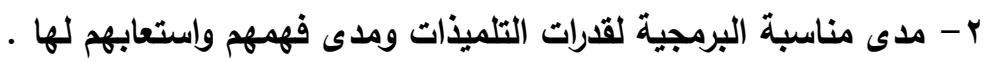

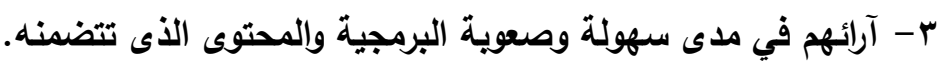
ع - اكتشاف ما بها من اخطاء فنية ومشكلات مختلفة. 


\section{ه- الاهتمام والاخذ والعمل بمقترحاتهر في تطوير البرمجية التعليمية .}

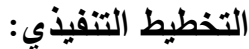

تحديد خطة السير في دروس محتوى البرمجية التعليمية بالاتتزام بما ورد بالنثرة الخاصة بمنهج التربية الرياضية الواردة

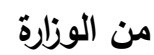

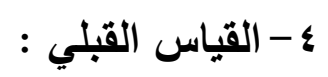

قامت الباحثة بإجراء القياسات القبلية علي افراد العينة (الضابطة- التجريبية ) في المتنيرات التي قد تؤئثر في نتائج

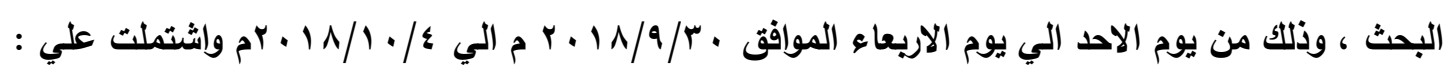

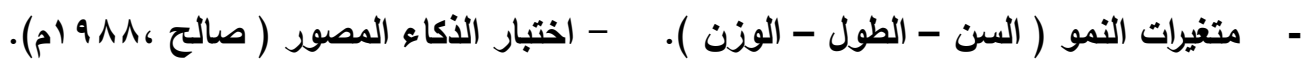

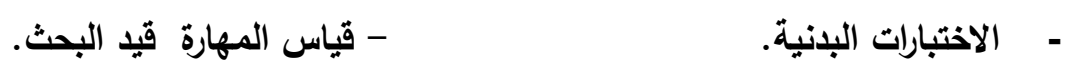

ه - تطبيق الاراسة الأساسية ( تطبيق البرنامج التدريسي المقترح )

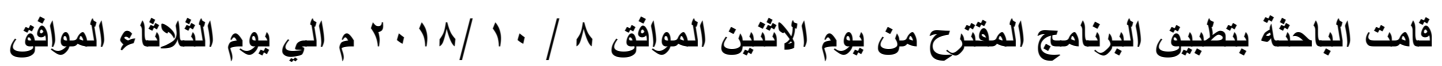

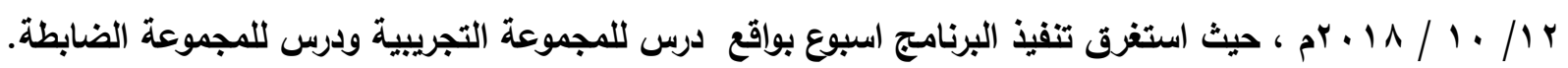

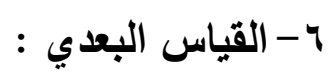

بعد الانتهاء من تنفيذ وتطبيق البرنامج ق قامت الباحثة باجراء القياس البعدي علي المجموعة التجريبية والضابطة من

تلميذات العينة الأساسية قيد البحث.

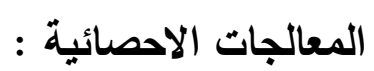

للتحقت من هذف البحث واختبارا لصحة الفروض استخدمت الباحثة حزمة للبرنامج الاحصائي للبحوث والعلوم

الاجتماعية (SPPS) في المعالجة الاحصائية للبيانات الأساسية باستخدام :

$$
\text { - } \text { - }
$$

عرض ومناقثة النتائج :

1- إن عرض نتائج الفرض الأول ومناقثتنها : 
جدول (^)

المتوسط الحسابي والانحراف المعياري للمجموعة الضابطة في القياسين القبلي والبعدى للاختبار المهاري قيد البحث

\begin{tabular}{|c|c|c|c|c|c|}
\hline \\
\hline \multicolumn{2}{|c|}{ القياس البعدى } & \multicolumn{2}{|c|}{ القياس القبلي } & \multirow{2}{*}{ الاختبارات / الاحصاء } & \\
\hline$\varepsilon \pm$ & س- & $\varepsilon \pm$ & س- س & & \\
\hline $0.9 \mathrm{~V}$ & $r \ldots \varepsilon$. & v.l. & 17.1. & خلايل (·لتمرير على الحائط & 1 \\
\hline
\end{tabular}

يتضح من الجدول (^) أن المتوسط الحسابي في القياس القبلي للاختبار المهاري التمرير من أعلى، قد بلغ للمجموعة

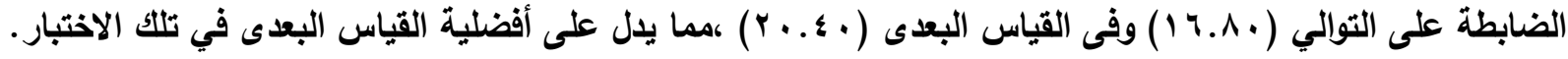

\section{جدول(9) (9) (9)}

دلالة الفروق بين القياسين القبلي والبعدي في درجة الاختبار المهاري لأفراد المجموعة الضابطة ن ا=ن ؟=. .

\begin{tabular}{|c|c|c|c|c|c|c|c|c|c|}
\hline \multirow{2}{*}{ الإحصائية } & \multirow{2}{*}{$(Z)$} & \multicolumn{2}{|c|}{ مجموع الرتب } & \multicolumn{2}{|c|}{ متوسط الرتب } & \multicolumn{2}{|c|}{ القياسات } & & \\
\hline & & ت & ت & ت & ت & ت & ت & & \\
\hline$\cdots 1$ & Y.V Y- & $\varepsilon 0 .$. & $\cdots$ & 0... & $\cdots$ & 9 & . & | (التمرير على الحائط خلال التمرير من أعلى & 1 \\
\hline
\end{tabular}

قيمة ويلككسون الجدوية (Z) = 1 عند مستوى دلالة إحصائية (ه . . )

يوضح الجدول (9) أن قيمة (z) المحسوية بتطبيق اختبار الإثارة لويلككسون لالالة الفروق بين القياسين القبلي

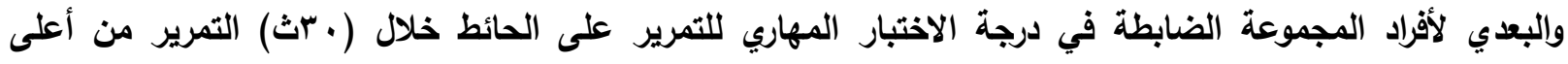

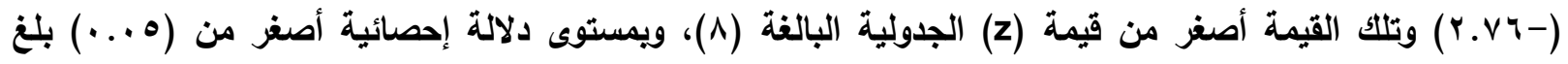
( 1 ( • )،ويعنى ذلك أن الفروق بين القياسين حقيقية ولصالح القياس البعدي ذا متوسط الرتب الأفضل.

1 - مناقشة نتائج الفرض الأول:

يوضح الجدول (9) والخاص بتطبيق اختبار ويلككسون لدلالة الفروق بين القياسين القبلي والبعدي لأفراد المجموعة الضابطة إلى أن هناك الفروق بين القياسين (القبلي والبعدى) وهذه الفروق حقيقية ولصالح القياس البعدي للمجموعة الضابطة.

وترجح الباحثة الفرق بين القياسين القبلي والبعدى إلى تأثير البرنامج التطليمي باستخدام أسلوب الأوامر(الثرح

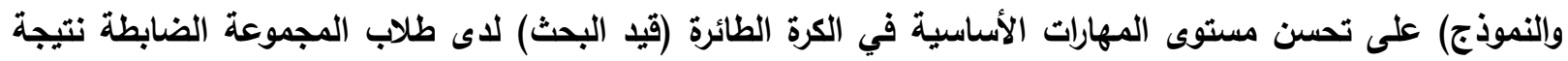


كما ترجع أن استخدام الطريقة التقليدية (أسلوب الأوامر) من قبل الشرح من خلال الشرح من قبل الباحثة مع أداء نموذج للمهارة له تأثير إيجابي على تعلم المهارات قيد البحث، فالتدريس باستخدام أسلوب الأوامر يؤدى إلى زيادة

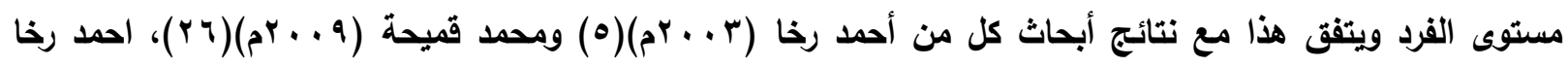

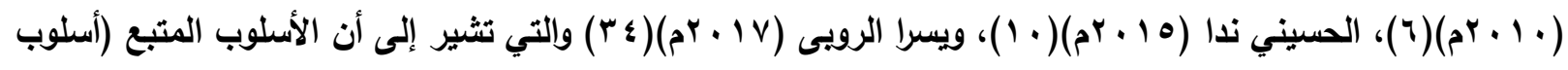

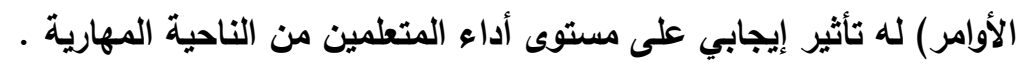

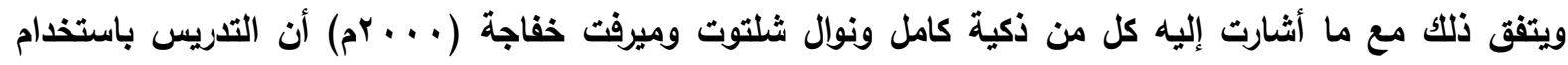
أسلوب الأوامر ( الشرح والنموذج) يؤدى إلى زيادة مستوى الفرد نتيجة للممارسة والأداء المتكرر والاسترجاع المباشر

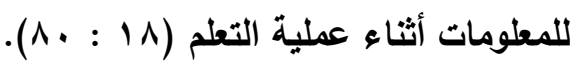
كما اتفق محروس محروس (10 • ب م) البرنامج هو الوسيلة الفعالة التي تساعد المربين في مجال التربية الرياضية علي تنفيذ مناهجه بأسلوب يقوم علي الأسس العلمية السليمة حيث تمكنهم في النهاية من تحقيق ما يبغون من أهداف $\cdot(r v: r r)$

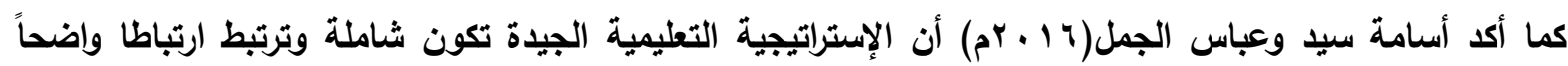
بالأهداف التربوية وتكون جذابة اى تحقق المتعة للمتعلم وتساعد على تعلمه تبعاً للأسلوب المتبع( (9 : 9 ). ويهذا يتحقق الفرض الأول كلياً والذي ينص على: " توجد فروق داله إحصائية بين القياسين القبلي والبعدي للمجموعة الضابطة في مستوي أداء مهارة التمرير من أعلي في الكرة الطائرة لتلميذات المرحلة الإعدادية لصالح القياس البعدي". ثانياً عرض ومناقشة نتائج الفرض الثاني: عرض نتائج الفرض الثاني جدول ( • 1 ) دلالة الفروق بين القياسين القبلي والبعدي في درجة

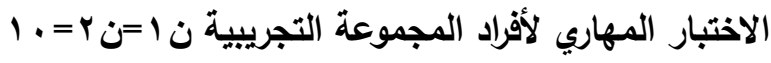

\begin{tabular}{|c|c|c|c|c|c|c|c|c|c|}
\hline \multirow{2}{*}{ الإحصائية } & \multirow{2}{*}{ (Z) } & \multicolumn{2}{|c|}{ مجموع الفروق } & \multicolumn{2}{|c|}{ متوسط الفروق } & \multicolumn{2}{|c|}{ |(القياسات } & \multirow{2}{*}{ الاحصاء } & \\
\hline & & ت & ت & ت & ت & ت & $1 ت$ & & \\
\hline$\cdots 1$ & Y.A $\leq-$ & $00 \ldots$ & $\cdots$ & 0.0. & $\cdots \cdot$ & $1 \cdot$ & • & | (التمرير على الحائط خلال| التمرير من أعلى| & 1 \\
\hline
\end{tabular}

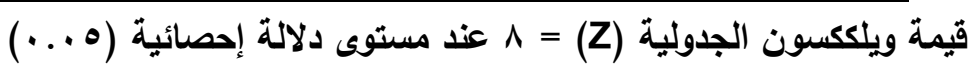

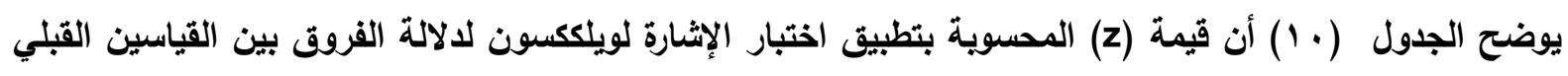

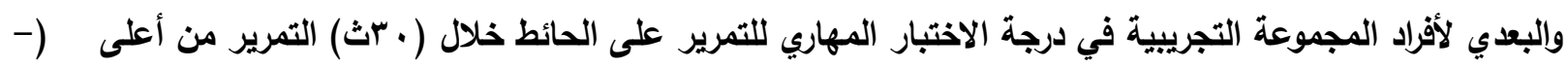


1-مناقشة نتائج الفرض الثاني:

يثير الجدول (· 1) الخاص بتطبيق اختبار الإشارة ويلككسون لالالة الفروق بين القياسين القبلي والبعدي لأفراد

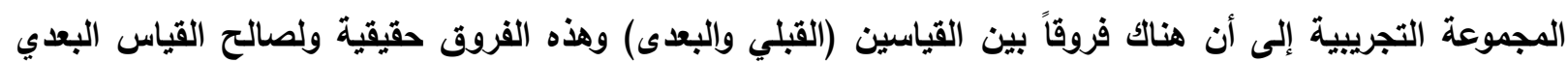

للمجموعة التجريبية.

وتعزى الباحثة ظهور تلك النتائج إلى تأثير برنامج تعليمي باستخدام الوسائط المتعددة في مستوي الأداء المهارى

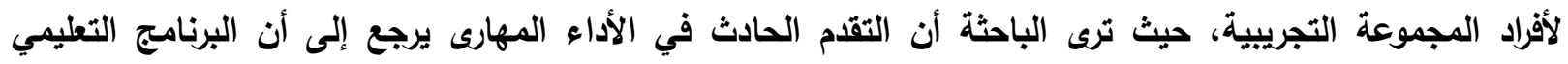

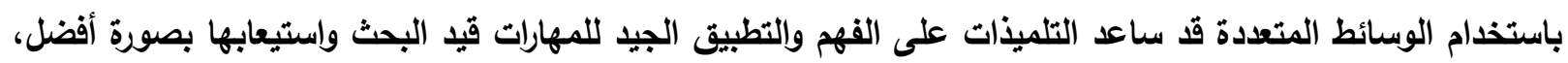

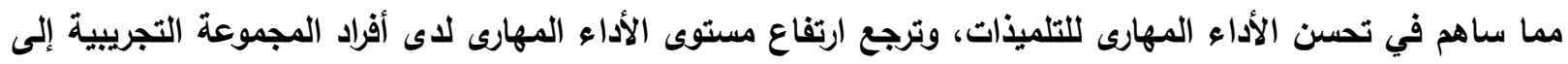

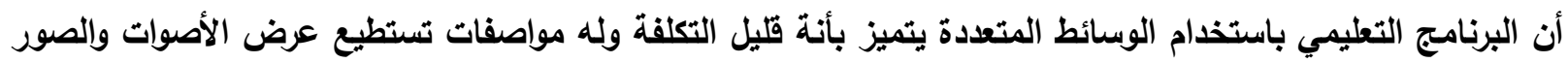
ومعالجتها لتحقيق تأثير تعليمي خاص على المتعلم كما إن إنتاج برامج متطورة للوسائط المتعددة التي تلبي احتياجات المستهلك والمتعلم تنشط العملية التعليمية باستخدام تكنولوجيا التعليم.

كما يعمل البرنامج التعليمي باستخدام الوسائط المتعددة على تقديم المادة المراد تعلمها بصورة شيقة وأكثر عمقاً ويالتالي تحقيق تعلم أفضل للطالبة، كما تساعد المتعلمين من كل الأعمار على التحول من النظام التلقيني المعتاد الي بلي

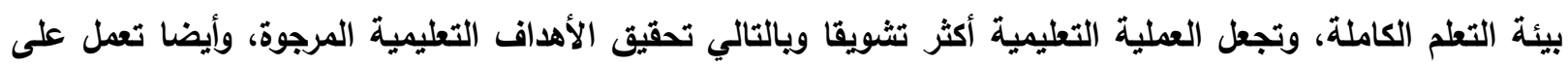
جذب الانتباه وإثارة اهتمامات المتعلم ومساعدته على اكتساب الخبرات وجعلها باقية الأثر، وتتكون من روابط فعالة تريط

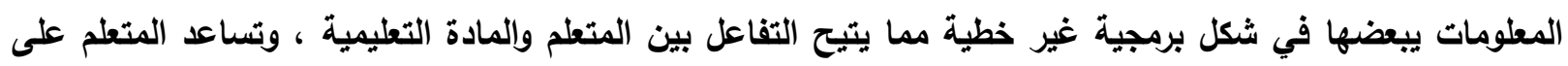

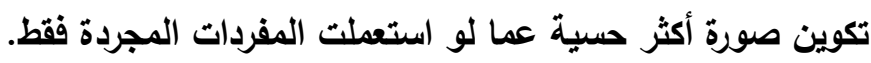

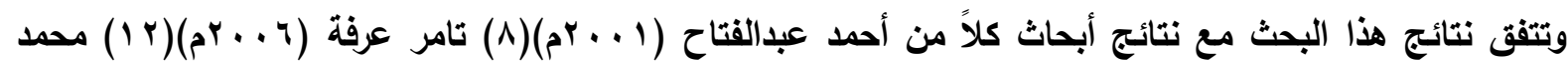

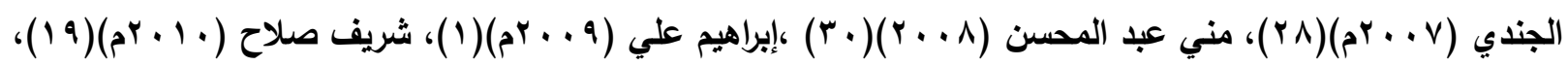

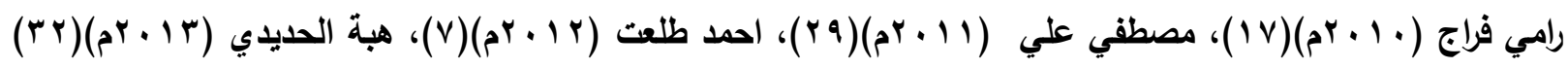
على أن استخدام الوسائط المتعددة في التعليم والبرمجيات التعليمية كان لها الأثر الفعال في حدوث التعلم بشكل أفضل على المتعلم.

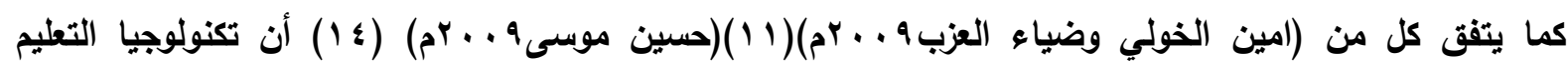
واستخدامات الحاسب الالى في التعليم يعمل على تنمية الاتجاهات والميول العلمية بين التلاميذ، والاهتمام بالتطور العلمي والتقني، كما يوسع آفاق المتعلم ومساعدته علي اختيار المهنة المناسبة وتقديس قيمة العمل، كما تنمي قدرة

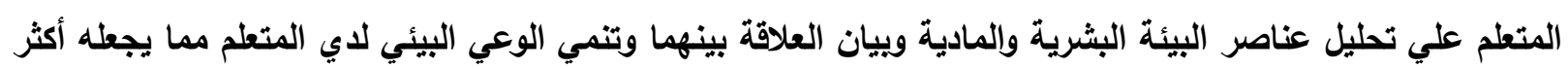

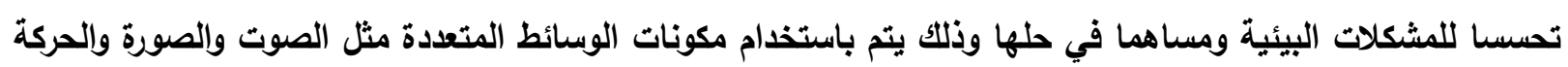
الحية كما أن برامج الوسائط المتعددة أصبحت شيقة وجذابة وتؤدي إلي استكثاف الكثير من الإمكانيات المعلوماتية وتعزى الباحثة ظهور تلك النتائج إلى أن الاهتمام باستخدام الوسائط المتعددة والبرمجية التعليمية في البرنامج التعليمي

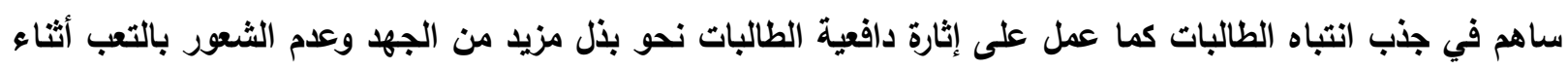


عملية التعلم، كما أتاح لطالبات المجموعة التجريبية فرصة وجود مواقف مشابهة للمواقف التي تواجههم في المباريات مما أدى إلى ارتفاع المستوى المهارى. وبهذا يتحقق الفرض الثاني كلياً والذي ينص على: "توجد فروق داله إحصائية بين القياسين القبلي والبعدي للمجموعة التجريبية في مستوي أداء مهارة التمرير من أعلي

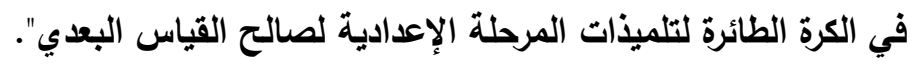
ثالثاً عرض ومناقشة الفرض الثالث: عرض نتائج الفرض الثالث

$$
\text { جدول (11) }
$$

المتوسط الحسابي والانحراف المعياري للمجموعتين الضابطة والتجريبية

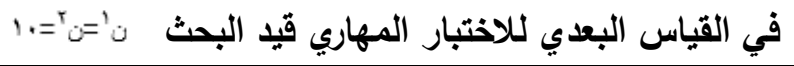

\begin{tabular}{|c|c|c|c|c|c|}
\hline \multicolumn{2}{|c|}{ المجموعة التجريبية } & \multicolumn{2}{|c|}{ المجموعة الضابطة } & \multirow{2}{*}{ الإحصاء } & \\
\hline$\varepsilon \pm$ & س- & $\varepsilon \pm$ & س- - - ل & & \\
\hline T.Y. & $\varepsilon \cdot .0$. & $0.9 \mathrm{~V}$ & r...s. & ( التمرير على الحائط خلال & 1 \\
\hline
\end{tabular}

يتضح من الجدول (11) أن المتوسط الحسابي في القياس البعدى للاختبار المهاري التمرير على الحائط خلال(· بث)

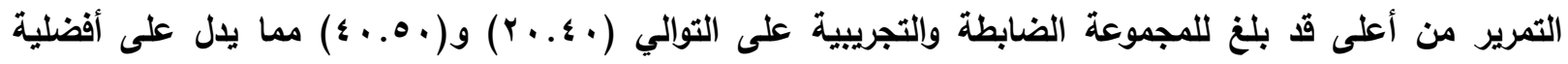
القياس البعدى للمجموعة التجريبية في تلك الاختبار

$$
\text { جدول (r) }
$$

\begin{tabular}{|c|c|c|c|c|c|c|c|c|c|}
\hline \multirow{2}{*}{ الإلالة } & \multirow{2}{*}{ (U) } & \multicolumn{2}{|c|}{ مجموع الرتب } & \multicolumn{2}{|c|}{ متوسط الرتب } & \multicolumn{2}{|c|}{ المجموعات } & \multirow{2}{*}{ |لاختبارات } & \multirow{2}{*}{ i } \\
\hline & & ت & ت & r & ت & ت & ت & & \\
\hline$\cdots$ & $\cdots$ & $100 \ldots$ & $00 \ldots$ & 10.0. & 0.0. & 1. & 1. & (التمرير على الحائط خلال & 1 \\
\hline
\end{tabular}

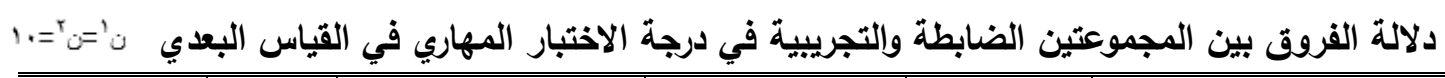

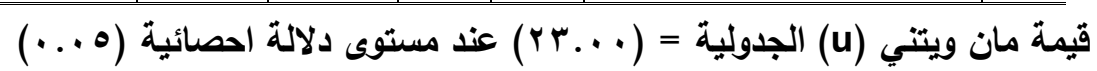

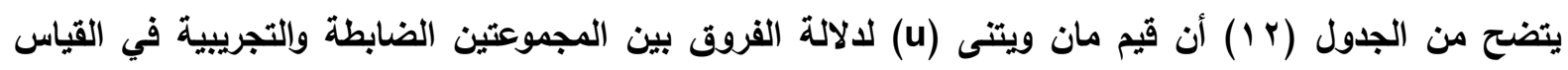

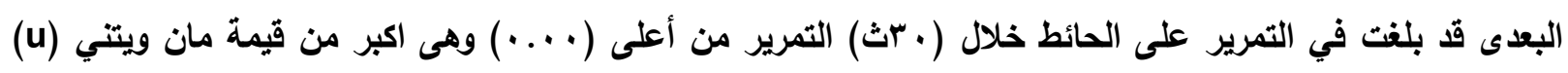

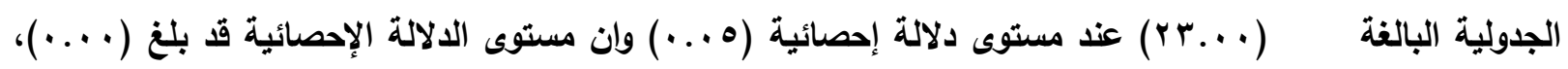


وتلك القيم أصغر من مستوى الدلالة الإحصائية (ه . . ) مما يدل على وجود فروق ذات دلالة إحصائية بين المجموعتين

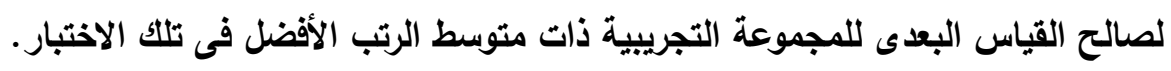

$$
\text { 1 - مناقشة نتائج الفرض الثالث: }
$$

يتضح من الجدول (r I) الخاص بتطبيق إختبار مان ويتنى u) لدلالة الفروق بين المجموعتين الضابطة والتجريبية

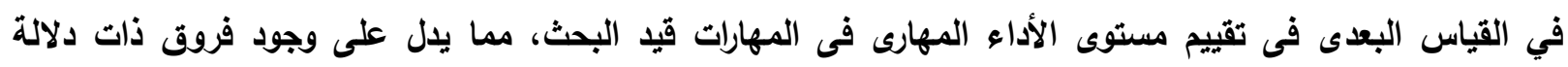
إحصائية بين المجموعتين لصالح القياس البعدى للمجموعة التجريبية تفوقاً ملحوظاً وارتفاعاً فى مستوى الأداء المهارى للمهارات قيد البحث.

وتعزى الباحثة ظهور تلكك النتائج إلى أن البرنامج التعليمي باستخدام الوسائط المتعددة في التعليم والمتبع مع

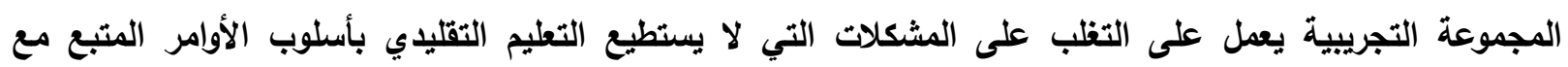
المجموعة الضابطة التظلب عليها مثل عدم مراعاة الفروق الفردية للمتعلمين وعدم كفاية وقت التطبيق لكثرة تدخل القائم

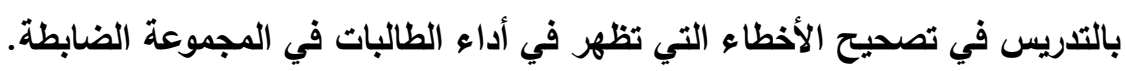

وأيضا تعزى الباحثة سبب تقدم وتفوق أفراد المجموعة التجريبية على أفراد المجموعة الضابطة في مستوى الأداء

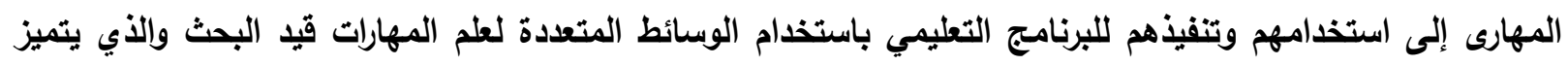
بمحتوى تعليمي شبة متكامل من حيث تخطيط المحتوى التعليمي وشبة متكامل من حيث تخطيط محتوى مقرر بصور

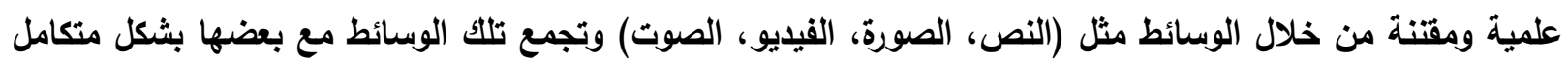
مما أدى إلى تعميق المعلومة وتأكدها لطالبات المجموعة التجريبية.

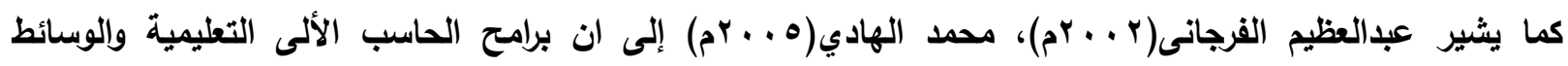

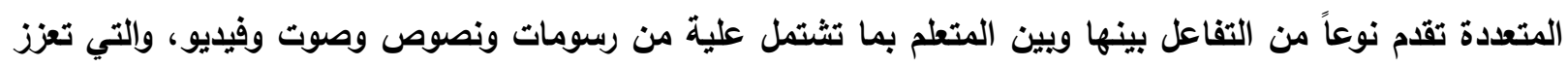

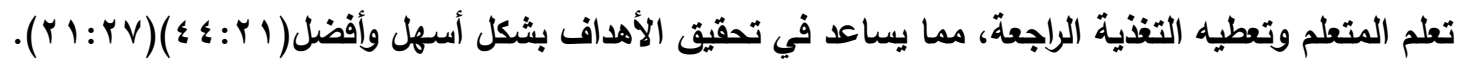

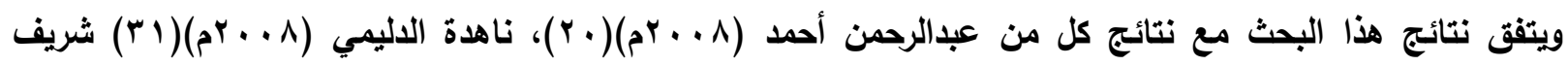

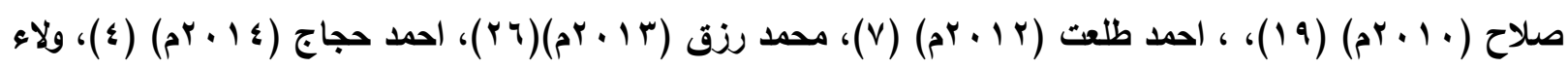

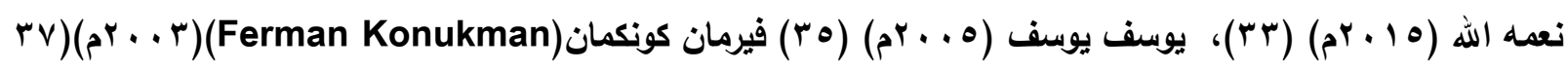

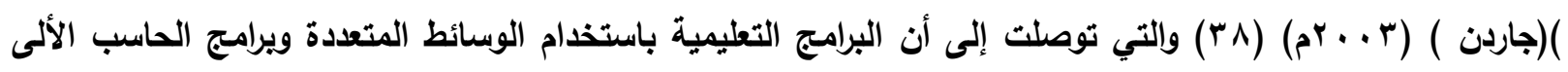

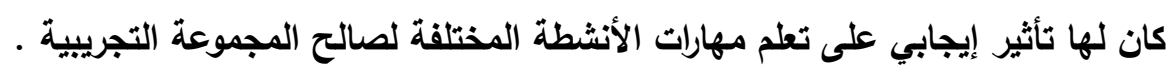

ويهذا يتحقق الفرض الثالث والذي ينص على:" توجد فروق داله إحصائية بين القياس البعدي للمجموعتين الضابطة

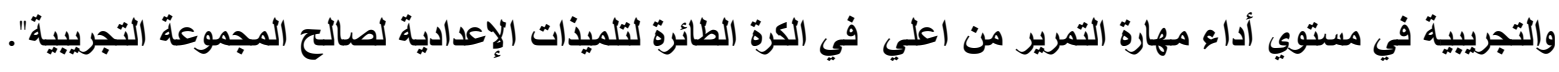


في ضوء نتائج البحث توصل الباحث إلى الاستتاجات الآتية:

ا - أن الأسلوب التقليدي له تأثير ايجابي على تحسين المستوى المهارى للتلاميذ في تعلم المهارات الأساسية للكرة

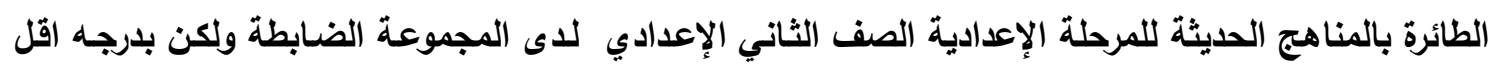

$$
\text { من التجريبية. }
$$

r- أن التعلم باستخدام الوسائط المتعددة له تأثير ايجابي وفعال على مستوى أداء المهارات الأساسية للكرة الطائرة

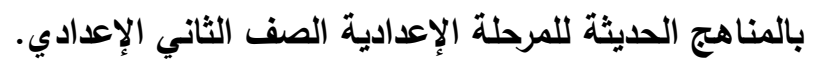

r- استخدام التعلم بالوسائط المتعددة أفضل من طريقه التعلم المتبعة في تعلم مهارات الكرة الطائرة .

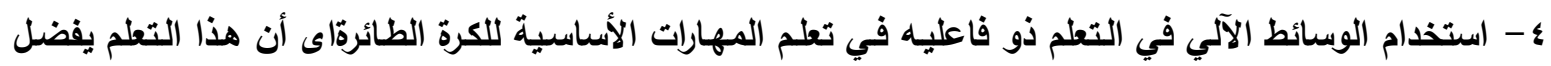
استخدامه في الألعاب الجماعية.

$$
\text { في ضوء ما أسفرت عنه نتائج البحث توصى الباحثة بما يلي: }
$$

- استخدام الوسائط المتعددة في تدريس الكرة الطائرة بالمناهج الحديثة للمرحلة الإعدادية الصف الثاني الإعدادي

لما له من تأثير ايجابي على مستوى الأداء وتحسين التعلم لدى التلميذات. r- الاهتمام باستخدام الوسائط المتعددة في تعلم مهارات الأنشطة الرياضية في المرئلة الادئة الإعدادية.

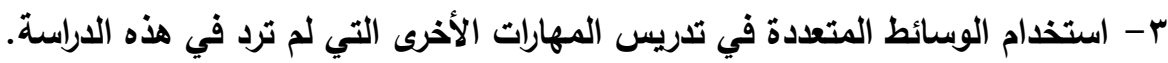

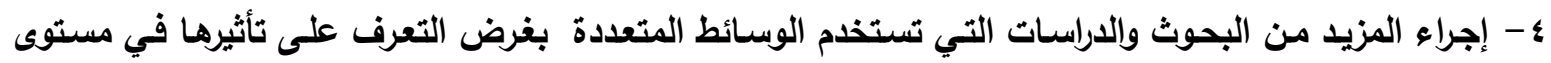

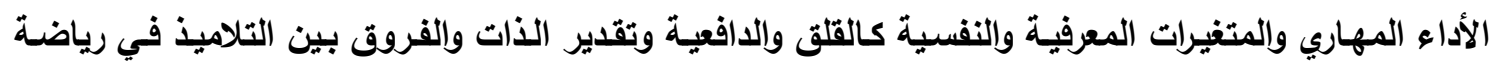
الكرة الطائرة. ه- الاهتمام بتطبيق أساليب التعلم الحديثة على تلميذات المرحلة الإعدادية الصف الثاني الإعدادي. צ- الاهتمام بإنشاء معمللتكنولوجيا التعلم بكليات التربية الرياضية. V- تنظيم دورات تدريب لصقل المدرسين بالخدمة وتدريبهم على استخدام الوسائط المتعددة. 


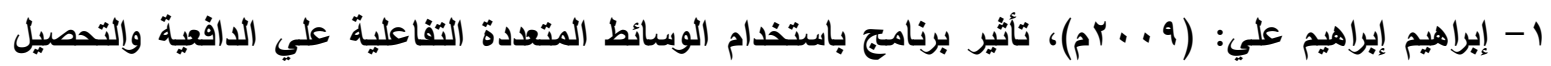

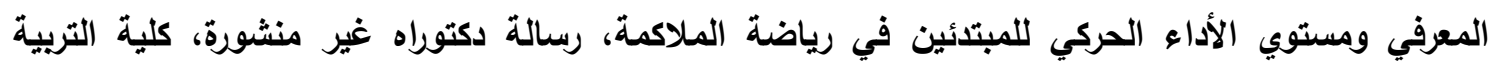

\section{الرياضية، جامعة المنصورة.}

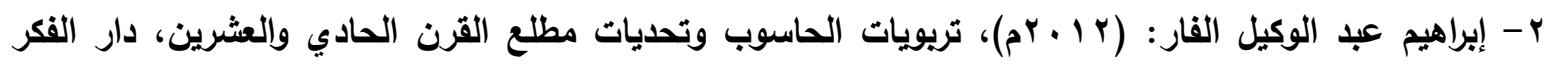

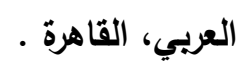

r- ايناس محمد حامد: (ه . . rم)، تطبيقات الحاسب الالي التصميم علي الحاسب الالي، دار النهضة العربية،

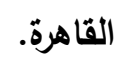

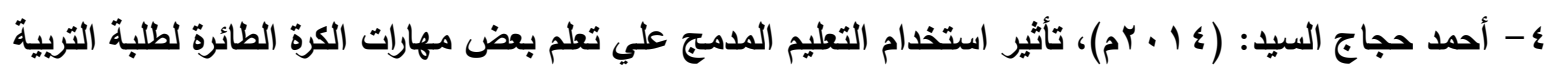

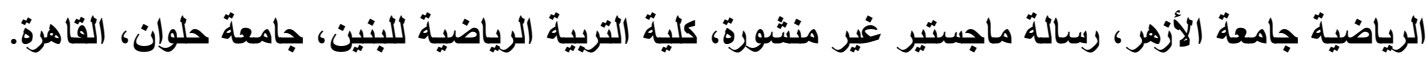

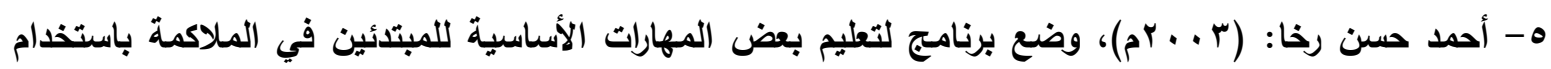
الكبيوتر، رسالة ماجستير غير منثورة، كلية التربية الرياضية، جامعة قناة السويس.

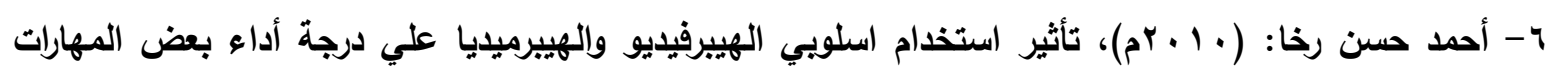

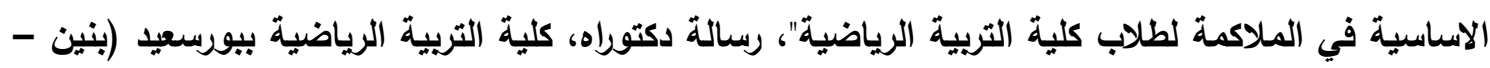
بنات)، جامعة قتاة السويس.

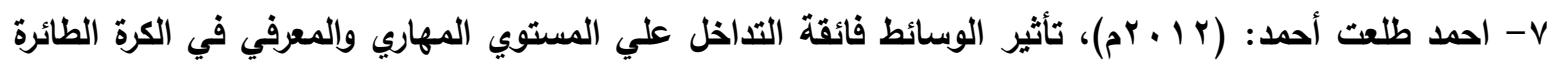

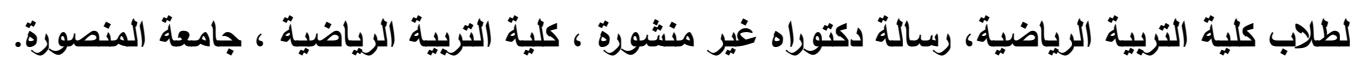

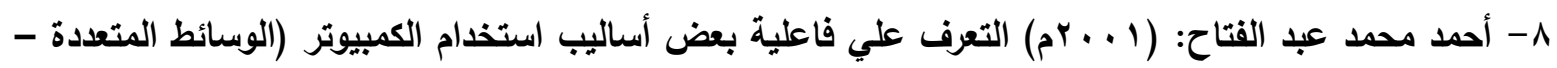

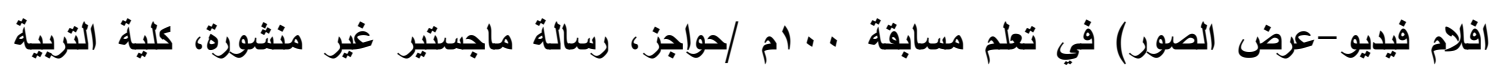
الزياضية للبنين، الزقازيق.

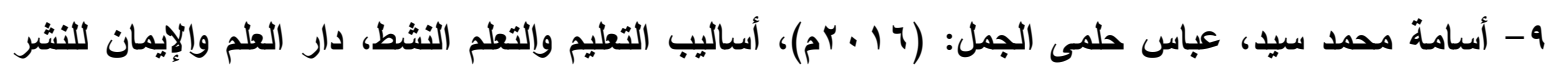
والتوزيع.

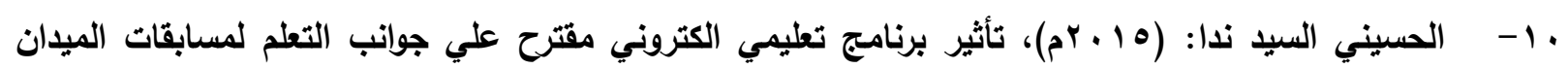

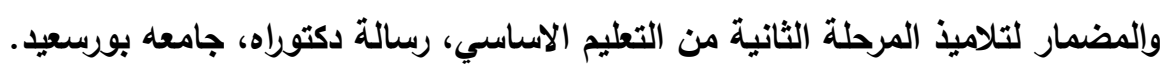

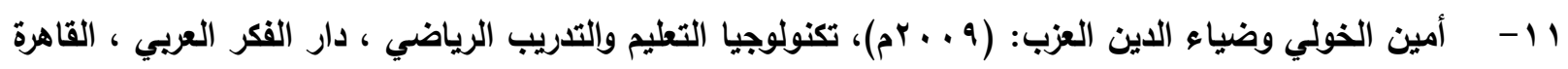

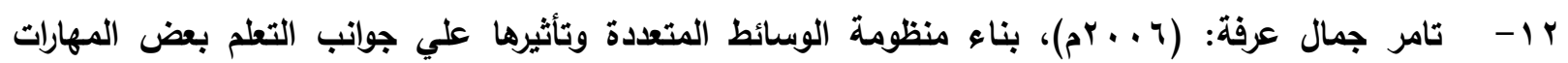
الاساسية للمبتائين في المبارزة، رسالة ماجستير غير منثورة، كلية التربية التربية الرياضية بينها، جامعة بنها.

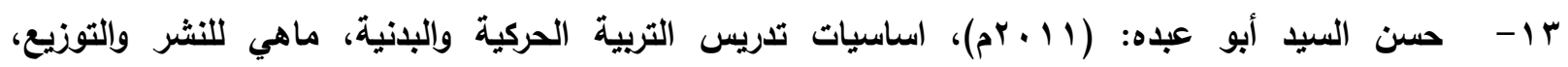

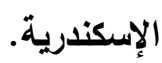

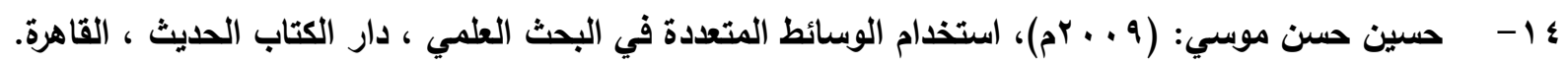

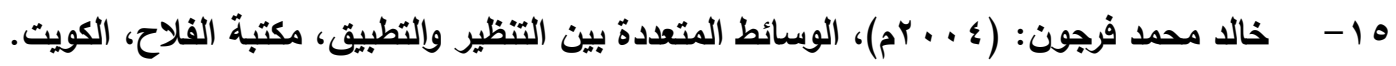




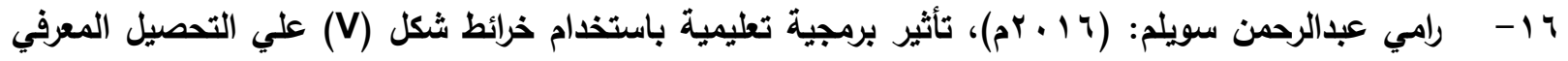
وتعلم بعض مهارات كرة طائرة لطلاب كلية التربية الرياضية ببورسعيد، رسالة ماجستير، كلية تربية رياضية بردية للبية لبنين والبنات، جامعة بورسعيد.

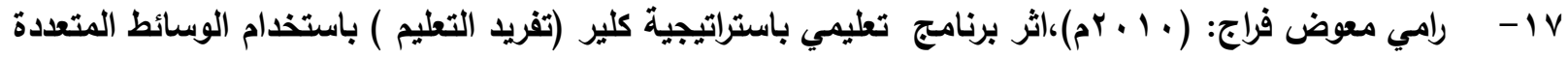
علي جوانب تعلم بعض المهارات الحركية بلرس التربية الرياضية، رسالة ماجستير غير منشورة ، معهذ البحوث والدراسات العربية ، قسم مناهج وطرق التدريس ، جامعة الدول العربية.

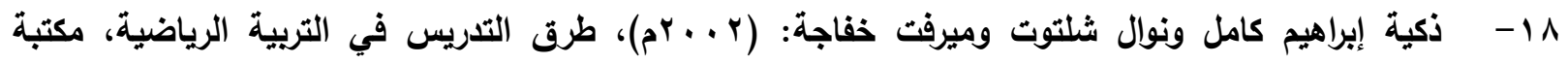
ومطبعة الإشعاع الفني ، الإسكندرية.

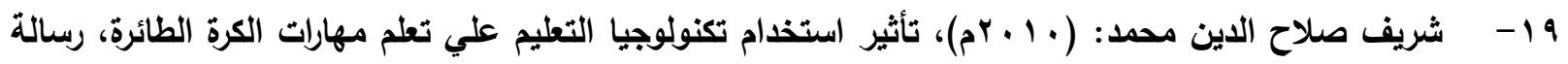
ماجستير غير منشورة ، كلية التربية الرياضية للبنين ، جامعة حلوان.

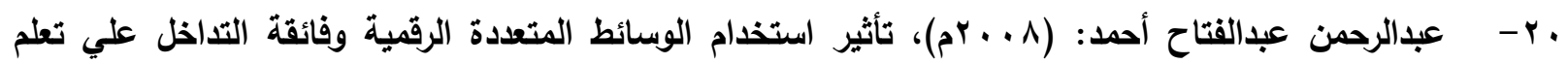
الوثب الثلاثي لتلاميذ المرحلة الاعدادية، رسالة ماجستير غير منشورة، كلية التربية الرياضية، جامعة المنصورة.

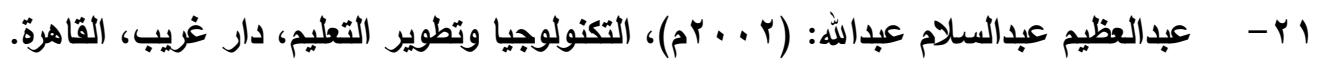

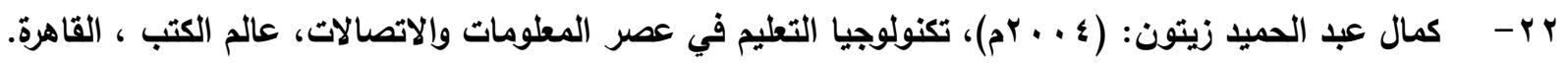

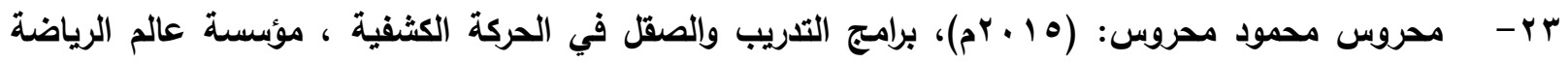
للنشر ودار الوفاء لانيا الطباعة ، الإسكندرية.

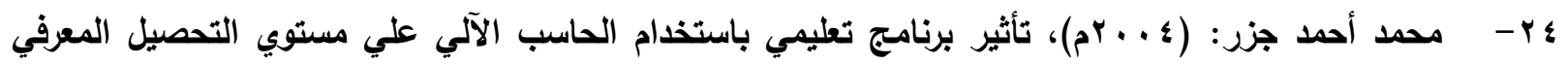

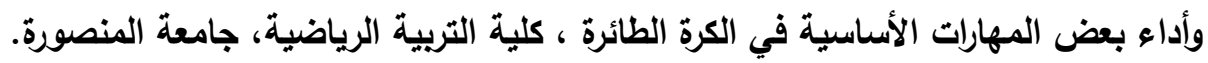

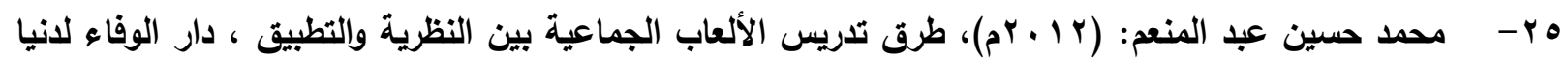
الطباعة والنشر ، الإسكندرية.

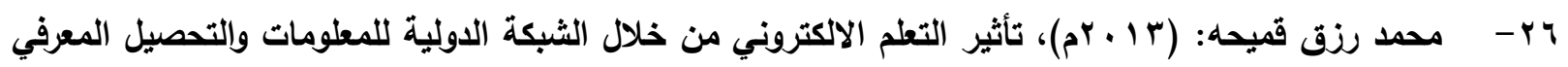

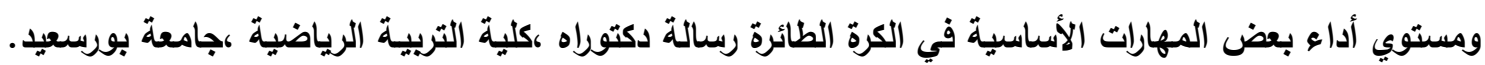

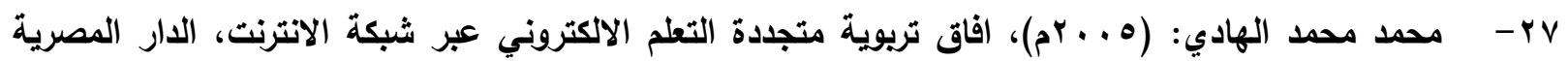
اللبنانية، القاهرة.

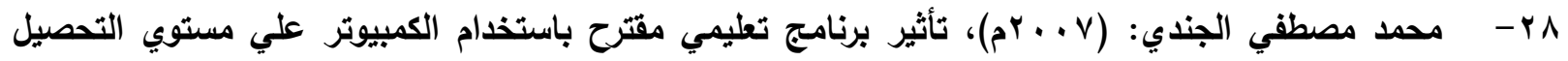

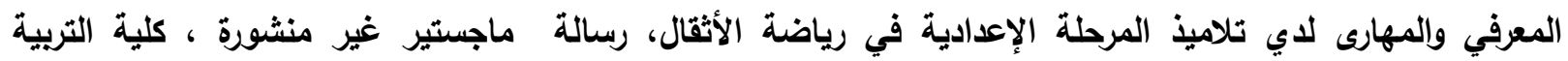
الرياضية، جامعة المنصورة.

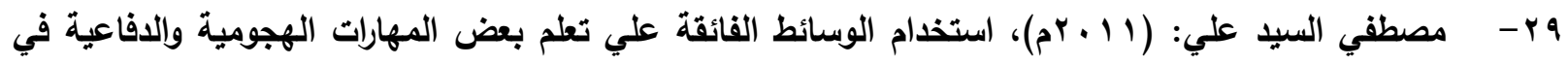
الكرة الطائرة، رسالة دكتوراه غير منشورة ، كلية التربية الرياضية للبنين، جامعة حلوان.

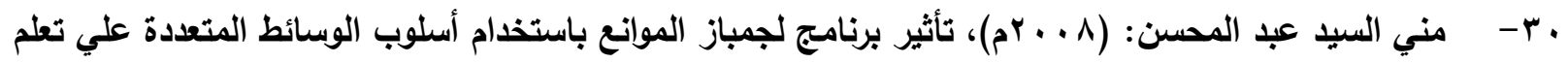
مهارة القفز فتحا علي المهر لتلميذات الحلقة الأولي من التعليم الأساسي، رسالة ماجستير، كلية التربية الرياضية، جامعة 


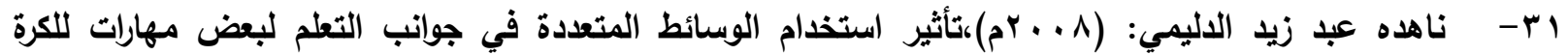
الطائرة، المجلات الأكاديمية العلمية العراقية، مجلة التربية الرياضية، المجلد العشرون، العدد الثالث، جامعة بغداد،

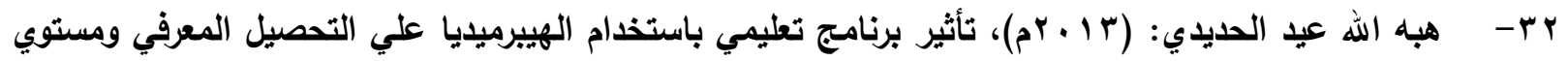
الأداء المهاري للمبتدئات في الوثب الطويل، رسائة ماجستير غير منشورة، كلية تربية رياضية للبنين والبنات، جامعة

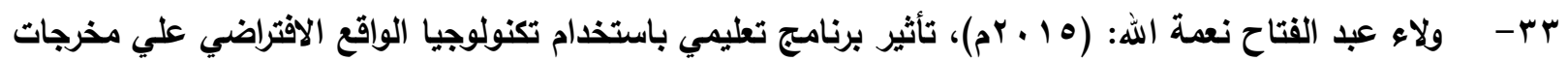

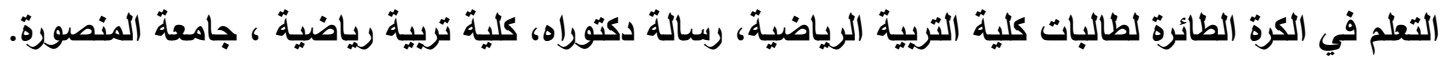

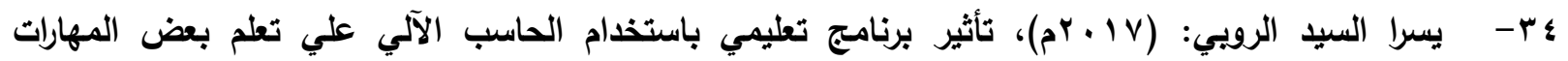

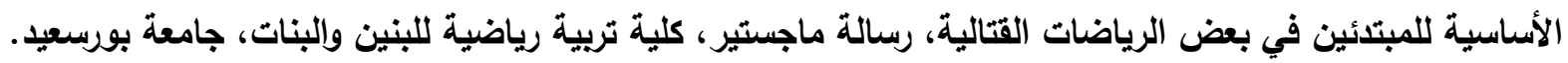

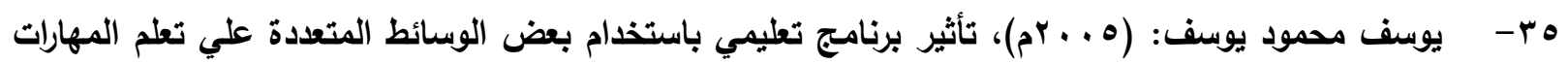

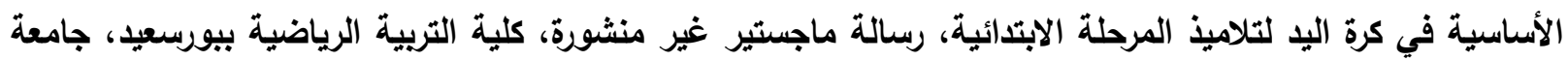

\section{ثانياً المراجع الأجنبية :}

36- Antoniou, P, (2010): Applying multimedia computer- assisted instruction to enhance physical education students' know of becket ball rules, Department of physical Education and Sport Science, Democritus University of Thrace, Greece.

37-Ferman, $K$, (2003): Effects of computer assisted multimedia teaching on tennis in physical education teacher, education, Blacksburg, Virginia, USA.

38-Gardener, D, (2003): Evaluating user interactive video user's perceptions of selfaccess language learning with multimedia movies, open university, United Kingdoms.

39-Jaccard, J, (1983): Statistics for the behavior sciences, worth publishing CO ,California, USA. 


\section{مستخلص البحث}

تأثير برنامج تعليمي باستخدام الوسائط المتعددة علي مستوي أداء مهارة التمرير من اعلي في الكرة الطائرة لتلميذات المرحلة الاعدادية

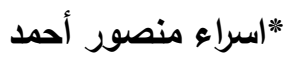

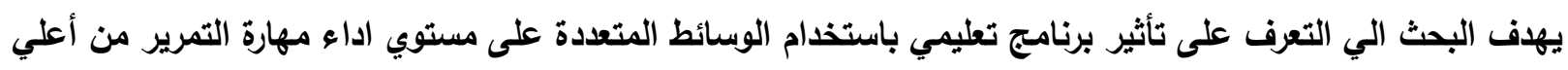

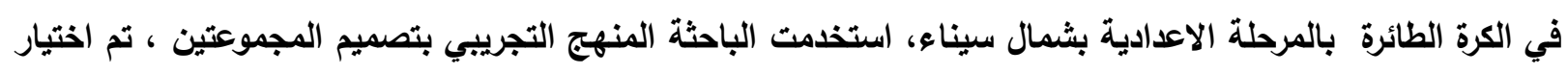

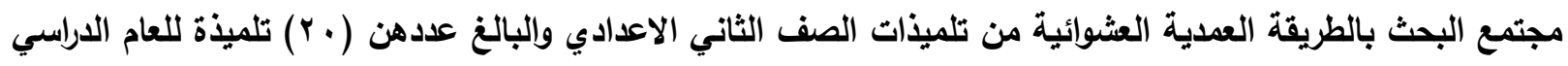

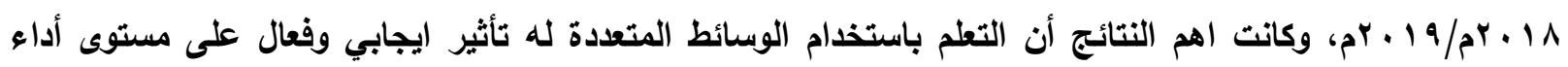
المهارات الأساسية للكرة الطائرة بالمناهج الصف الثاني الني بالمرحلة الإعدادي. الكلمات المفتاحية : الوسائط المتعددة ، المرحلة الإعدادية 


\begin{abstract}
Effect of an educational program using multimedia on level of performance of over passing skill of in the volleyball to junior high school girls
\end{abstract}

\title{
*Asra Mansour Ahmed
}

The aim of the research is to identify effect of a multimedia-based educational program on the level of over passing skill of volleyball in the preparatory stage in North Sinai, the researcher used the experimental method two groups design' research sample was randomly chosen from the second grade femal pupils $(n=20)$ for the academic year 2018/2019. the important results showed that learning using multimedia has a positive effect on the level of performance of the basic skills of volleyball in the modern curricula of Second Grade Preparatory Stage.

Key words : Multimedia, Preparatory Stage 